\title{
Amyloid $\beta$-Induced Death in Neurons Involves Glial and Neuronal Hemichannels
}

\author{
Juan A. Orellana, ${ }^{1}$ Kenji F. Shoji, ${ }^{1}$ Verónica Abudara,,${ }^{2,3}$ Pascal Ezan, ${ }^{2}$ Edwige Amigou, ${ }^{2}$ Pablo J. Sáez, ${ }^{1}$ Jean X. Jiang, ${ }^{4}$ \\ Christian C. Naus, ${ }^{5}$ Juan C. Sáez, ${ }^{1,6}$ and Christian Giaume ${ }^{2}$ \\ ${ }^{1}$ Departamento de Fisiología, Pontificia Universidad Católica de Chile, Santiago 6513677, Chile, ${ }^{2}$ Inserm, Unité 840, Collège de France, 75231 Paris Cedex \\ 05, France, ${ }^{3}$ Departamento de Fisiología, Facultad de Medicina, Universidad de la República, 11800 Montevideo, Uruguay, ${ }^{4}$ Department of Biochemistry, \\ University of Texas Health Science Center, San Antonio, Texas 78229, ${ }^{5}$ Department of Cellular and Physiological Sciences, Life Sciences Institute, University \\ of British Columbia, Vancouver, British Columbia V6T 1Z3, Canada, and 'Instituto Milenio, Centro Interdisciplinario de Neurociencias de Valparaíso, \\ Valparaíso 2340000, Chile
}

The mechanisms involved in Alzheimer's disease are not completely understood and how glial cells contribute to this neurodegenerative disease remains to be elucidated. Because inflammatory treatments and products released from activated microglia increase glial hemichannel activity, we investigated whether amyloid- $\beta$ peptide $(\mathrm{A} \beta)$ could regulate these channels in glial cells and affect neuronal viability. Microglia, astrocytes, or neuronal cultures as well as acute hippocampal slices made from GFAP-eGFP transgenic mice were treated with the active fragment of $\mathrm{A} \beta$. Hemichannel activity was monitored by single-channel recordings and by time-lapse ethidium uptake, whereas neuronal death was assessed by Fluoro-Jade $\mathrm{C}$ staining. We report that low concentrations of $\mathrm{A} \beta_{25-35}$ increased hemichannel activity in all three cell types and microglia initiate these effects triggered by A $\beta$. Finally, neuronal damage occurs by activation of neuronal hemichannels induced by ATP and glutamate released from A $\beta_{25-35}$-activated glia. These responses were observed in the presence of external calcium and were differently inhibited by hemichannel blockers, whereas the $\mathrm{A} \beta_{25-35}$-induced neuronal damage was importantly reduced in acute slices made from $\mathrm{Cx} 43$ knock-out mice. Thus, $\mathrm{A} \beta$ leads to a cascade of hemichannel activation in which microglia promote the release of glutamate and ATP through glial (microglia and astrocytes) hemichannels that induces neuronal death by triggering hemichannels in neurons. Consequently, this work opens novel avenues for alternative treatments that target glial cells and neurons to maintain neuronal survival in the presence of $\mathrm{A} \beta$.

\section{Introduction}

Alzheimer's disease (AD) is an age-related neurodegenerative disease that results in memory loss, behavior and personality changes, among other symptoms. The generation of amyloid plaques in the extracellular brain parenchyma composed by amyloid- $\beta$ (A $\beta$ ) peptide (LaFerla et al., 2007) and reactive gliosis are among tissue manifestations. $A \beta$ is a peptide generated by proteolytic cleavage of APP (amyloid precursor protein) (LaFerla et al., 2007) and its fragment, 25-35 (A $\left.\beta_{25-35}\right)$, contains the neurotoxic $\mathrm{A} \beta$ domain (Pike et al., 1995b). Although $\mathrm{A} \beta$ neurotoxicity involves activation of NMDA receptors, sustained elevations of $\left[\mathrm{Ca}^{2+}\right]_{\mathrm{i}}$, and oxidative stress (LaFerla et al., 2007), the full

Received Dec. 9, 2010; revised Jan. 17, 2011; accepted Jan. 30, 2011.

This work was partially supported by the Caisse de Retraite et de Prévoyance des Clercs et Employés de Notaires and Inserm (France) (C.G.), Comisión Nacional de Investigación Científica y Tecnológica Grant 24080055 (J.A.0.), Fondo Nacional de Desarrollo Científico y Tecnológico Grant 1070591 (J.C.S.), Fondo de Fomento al Desarrollo Científico y Tecnológico Grant D0711086 (J.C.S.), Anillo Grant ACT-71 (J.C.S.), Institut National de la Santé et de le Recherche Medicale (France) (Département des Relations Internationales) (J.A.O.), Heart and Stroke Foundation of British Columbia and Yukon (C.C.N.), and National Institutes of Health Grant AR46798 and Welch Foundation Grant AQ-1507 (J.X.J.). The data of this work were presented by Dr. Juan A. Orellana as partial fulfillment of the requirements to obtain the degree of PhD in Physiological Sciences at the Pontificia Universidad Católica de Chile.

Correspondence should be addressed to Dr. Juan A. Orellana, Departamento de Fisiología, Pontificia Universidad Católica de Chile, Alameda 340, Santiago 6513677, Chile. E-mail: jaorella@uc.cl.

DOI:10.1523/JNEUROSCI.6417-10.2011

Copyright $\odot 2011$ the authors $\quad 0270-6474 / 11 / 314962-16 \$ 15.00 / 0$ underlying mechanism associated with $\mathrm{AD}$ remains to be elucidated.

Brains from $\mathrm{AD}$ patients exhibit a reactive gliosis characterized by glial activation closely associated with amyloid plaques (Kalaria, 1999). Moreover, it has been reported that the immunoreactivity of connexin 43 ( $\mathrm{Cx} 43)$, a gap junction channel and hemichannel protein subunit (Sáez et al., 2003), is increased around amyloid plaques (Nagy et al., 1996; Mei et al., 2010). Gap junctions are membrane specializations that provide a direct cytoplasmic pathway between contacting cells by aggregates that contain a few tens to thousands of cell-to-cell channels, termed gap junction channels (Sáez et al., 2003). They are formed by the docking of two hemichannels, contributed by each contacting cell (Sáez et al., 2003). Each hemichannel is formed by oligomerization of connexins, which are expressed by astrocytes, microglia, and neurons (Orellana et al., 2009). A more recently described three-member protein family, termed pannexins (Panxs), can also form hemichannels at the cell surface of diverse mammalian cells (Scemes et al., 2009) and have been proposed to play a relevant role in inflammasome activation in astrocytes and neurons (Iglesias et al., 2009).

It has been proposed that, under chronic pathological conditions (e.g., AD), activated microglia release proinflammatory molecules that increase hemichannel opening and reduce gap junctional communication in astrocytes, depriving neurons of 
glial protective functions and further reducing neuronal viability (Orellana et al., 2009). In fact, increased hemichannel activity occurs in astrocytes, microglia, and neurons under in vitro conditions that mimic pathological situations (Takeuchi et al., 2006; Thompson et al., 2006; Orellana et al., 2010). Therefore, our interest was to examine whether $\mathrm{A} \beta_{25-35}$, the active fragment of this peptide, could modulate hemichannel activity in primary cultures of astrocytes, microglia, and neurons, as well as in astrocytes and neurons studied in acute hippocampal slices.

We found that $A \beta_{25-35}$ increases the hemichannel activity in cultures of microglia, astrocytes, and neurons in a concentrationand time-dependent manner. Moreover, astroglial hemichannel activity was also induced by $\mathrm{A} \beta_{25-35}$ in acute hippocampal slices and promoted neuronal death, which was abolished by hemichannel blockers. Together, these findings demonstrate a cascade of molecular and cellular events leading to neuronal death in which glial hemichannels play a central role. These observations open the way for alternative therapeutic strategies targeting glial and neuronal hemichannels to prevent and/or slow down neurodegenerative processes occurring in $\mathrm{AD}$.

\section{Materials and Methods}

\section{Reagents and antibodies}

Chemiluminescence detection kit was purchased from GE Healthcare. Anti-rabbit IgG antibody conjugated to horseradish peroxidase was purchased from Pierce. Gap26, Gap27, ${ }^{10}$ panx1, and E1b peptides were obtained from NeoMPS. $\mathrm{A} \beta_{25-35}$ and $\mathrm{A} \beta_{35-25}$ were purchased from Bachem. HEPES, DMEM, $\mathrm{H}_{2} \mathrm{O}(\mathrm{W} 3500), \mathrm{LaCl}_{3}\left(\mathrm{La}^{3+}\right)$, ethidium (Et) bromide, 2-arachidonyl-glycerol (2-AG), cytosine arabinoside (Ara-C), anti-MAP2 monoclonal antibody H-M2, and probenecid (Prob) were purchased from Sigma-Aldrich. Fetal calf serum (FCS) was obtained from HyClone. Penicillin, Neurobasal medium, B27 supplement, glutamax, streptomycin, isolectin GS-IB4 488 and 555, anti-CD11b, goat anti-mouse Alexa Fluor 488, and goat anti-mouse Alexa Fluor 555 were obtained from Invitrogen. Anti-NeuN monoclonal antibody and Fluoro-Jade C (F-Jade) were obtained from Millipore Bioscience Research Reagents. Normal goat serum (NGS) was purchased from Zymed. Anti-GFAP monoclonal antibody was purchased from ICN Chemicals. Anti-Cx43 monoclonal antibody was obtained from BD Biosciences. $\mathrm{Cx} 43^{\mathrm{E} 2}$ antibody specifically for blocking hemichannels was generated and affinity purified as previously described (Siller-Jackson et al., 2008).

\section{Animals}

Animal experiments were in accordance with the European Community Council Directives of November 24, 1986. Cell cultures were prepared from male OF1 mice (Charles River). In addition, Cx43-deficient astrocytes and microglia were obtained from male Cx43 knock-out (KO) $\left(\mathrm{Cx} 43^{-1-}\right)$ mice, whereas control $\mathrm{Cx} 43^{+/+}$wild-type astrocytes were cultured from male mice with the same genetic background (Reaume et al., 1995). $\mathrm{Cx} 43^{-1-}$ and $\mathrm{Cx} 43^{+/+}$mutant mice were generated by mating between heterozygous $\mathrm{Cx} 43^{+/-}$.

Hippocampal slices were prepared from male wild-type ${ }^{+/+}$and transgenic mice, including $\mathrm{Cx} 30^{-/-}, \mathrm{Cx} 43^{\mathrm{fl} / \mathrm{fl}}$ : GFAP-cre $\left(\mathrm{Cx} 43^{-/-}\right)$, a conditional $\mathrm{KO}$ of $\mathrm{Cx} 43$ in astrocytes, $\mathrm{Cx} 30^{-1-} \mathrm{Cx} 43^{\mathrm{f} / \mathrm{fl}}$ : GFAP-cre $\left(\mathrm{C} \times 30^{-1-} \mathrm{Cx} 43^{-1-}\right)$, a double $\mathrm{KO}$ of $\mathrm{Cx} 30$ and $\mathrm{Cx} 43$ in astrocytes and GFAP-eGFP mice. Genotyping was performed from a tissue sample, using PCR analysis, as described previously (Retamal et al., 2007). The sequence of the immunogenic peptide corresponds to a region of the $\mathrm{C}$ terminus that is conserved in human, mouse, and rat Pxl (residues CNLGMIKMD) but is not found in Px2, Px3, or other proteins. The peptide was conjugated to Blue Carrier (hemocyanin from Concholepas concholepas, Biosonda) using glutaraldehyde. Immunization of rabbits and collection of sera were performed by Bios Chile.

\section{Cell cultures}

Microglial cultures. Microglia cultures were prepared from cortex of postnatal day 1 (P1) OF1 mice as described previously (Orellana et al., 2010).
Briefly, dissected meninges were carefully peeled off and cortices were mechanically dissociated. Cells were seeded into $100-\mathrm{mm}$-diameter culture dishes at $5 \times 10^{6}$ cells/dish in DMEM, containing $10 \%$ heatinactivated FCS (Abcys). The medium was changed at 1 and $3 \mathrm{~d}$ in vitro (DIV) and microglia were collected at 10 DIV by shaking the culture dishes. Microglia were seeded onto $35 \mathrm{~mm}$ dishes $\left(2 \times 10^{6}\right.$ cells/dish $)$ or onto glass coverslips placed inside 16 -mm-diameter 24 -well plastic plates $\left(5 \times 10^{5}\right.$ cells/well $)$ in DMEM containing $10 \%$ FCS.

$\mathrm{C} \times 43^{-/-}$and $\mathrm{C} \times 43^{+/+}$microglial cultures. These microglia cultures were prepared from the cortex of newborn $\mathrm{Cx} 43$-deficient mice, as described above for OF1 mice, and cells were maintained in the same conditions mentioned previously for microglial cultures.

Astrocyte cultures. These cultures were prepared by the same protocol used for microglia mentioned previously. Cells were seeded onto $35 \mathrm{~mm}$ plastic dishes (Nunclon) or onto glass coverslips (Gassalem) placed inside $16 \mathrm{~mm} 24$-well plastic plates (Nunclon) at the density of $5 \times 10^{5}$ cells/dish or $1 \times 10^{5}$ cells/well, respectively, in DMEM, supplemented with penicillin $(5 \mathrm{U} / \mathrm{ml})$, streptomycin $(5 \mu \mathrm{g} / \mathrm{ml})$, and 10\% FCS. After 8-10 DIV , $1 \mu \mathrm{M}$ cytosine-arabinoside was added during $3 \mathrm{~d}$ to eliminate proliferating microglial cells. Medium was changed twice a week and cultures were used after 3 weeks. These cultures contained $>95 \%$ GFAP + cells and $>95 \%$ S100 $\beta+$ cells. No neuronal cells were detected as judged by MAP2 staining (data not shown).

$\mathrm{C} \times 43^{-/-}$and $\mathrm{C} \times 43^{+/+}$astrocyte cultures. These astrocyte cultures were prepared from the cortex of P1 Cx43-deficient mice, as described above for OF1 mice.

Neuronal cultures. Cortical neurons were obtained from cerebral cortices of embryonic day 16 mice. Briefly, cortices were dissected as mentioned above for astrocyte cultures. Cells were seeded directly on polyornithine-coated coverslips $\left(1 \times 10^{5}\right.$ cells/coverslip $)$ or into $35 \mathrm{~mm}$ culture dishes $\left(5 \times 10^{5}\right.$ cells/dish $)$ in Neurobasal medium supplemented with penicillin $(5 \mathrm{U} / \mathrm{ml})$, streptomycin $(5 \mu \mathrm{g} / \mathrm{ml})$, B27 supplement, and glutamax. Partial medium changes $(1 / 4)$ were done twice a week.

\section{Acute hippocampal slices}

Acute transverse hippocampal slices $(300-400 \mu \mathrm{m})$ were prepared from wild-type ${ }^{+/+}$, transgenic GFAP-eGFP, Cx43 $3^{-/-}$, and Cx $30^{-/-}$ $\mathrm{Cx} 43^{-1-}$ mice. Mice were decapitated, and their brains were dissected and placed in ice-cold artificial CSF (ACSF) containing the following (in mM): $125 \mathrm{NaCl}, 2.5 \mathrm{KCl}, 25$ glucose, $25 \mathrm{NaHCO}_{3}, 1.25 \mathrm{NaH}_{2} \mathrm{PO}_{4}, 2$ $\mathrm{CaCl}_{2}$, and $1 \mathrm{MgCl}_{2}$, bubbled with $95 \% \mathrm{O}_{2} / 5 \% \mathrm{CO}_{2}, \mathrm{pH}$ 7.4. Hippocampal coronal brain slices were cut using a vibratome (VT 1000GS; Leica) filled with ice-cold ACSF. The slices were transferred at room temperature $\left(20-22^{\circ} \mathrm{C}\right)$ to a holding chamber and immersed in oxygenated ACSF, pH 7.4, for a stabilization period of $1 \mathrm{~h}$ before being used.

\section{Treatments}

Microglia, astrocytes, and neurons were treated for 24,48 , or $72 \mathrm{~h}$ with $0.1,1$, or $10 \mu \mathrm{MA} \beta_{25-35}$ prepared in water [ $1 \mathrm{~d}$ of solubilization and stored rapidly at $-20^{\circ} \mathrm{C}$, conditions that allow mainly the monomer form of the peptide (Pike et al., 1995a)] and kept in normal culture conditions, whereas acute slices were treated for $3 \mathrm{~h}$ with $10 \mu \mathrm{M} \mathrm{A} \beta_{25-35}$ and kept under conditions mentioned above. Control cultures were treated with the inverse sequence of $\mathrm{A} \beta_{25-35}$ which has no biological effect. To obtain conditioned medium from microglia (CM-microglia) or astrocytes (CM-astrocyte), cultures of each cell type were treated with $10 \mu \mathrm{M} \mathrm{A} \beta_{25-35}$ for $72 \mathrm{~h}$. Supernatants were collected, filtered $(0.22 \mu \mathrm{m})$, and stored at $-20^{\circ} \mathrm{C}$ before being used for experiments. Connexin hemichannel blockers, including $\mathrm{La}^{3+}$, synthetic mimetic peptides (Gap26 and Gap27; $200 \mu \mathrm{M})$, and Cx43E2 (1:500), and the pannexin hemichannel blockers, ${ }^{10}$ panx1 $(200 \mu \mathrm{M}), \mathrm{E} 1 \mathrm{~b}(200 \mu \mathrm{M})$, and Prob $(500 \mu \mathrm{M})$, were coapplied with Et for "snapshot" experiments or preincubated for $30 \mathrm{~min}$ before electrophysiological experiments.

\section{Dye uptake and time-lapse fluorescence imaging}

Cultures. For snapshot experiments, control and treated cells were exposed to $5 \mu \mathrm{M}$ Et bromide for $10 \mathrm{~min}$ at $37^{\circ} \mathrm{C}$. Then, cells were washed with HBSS (in mM: $137 \mathrm{NaCl}, 5.4 \mathrm{KCl}, 0.34 \mathrm{Na}_{2} \mathrm{HPO}_{4}, 0.44 \mathrm{KH}_{2} \mathrm{PO}_{4}, 1.2$ $\mathrm{CaCl}_{2}, \mathrm{pH}$ 7.4) and examined by epifluorescence as described previously (Orellana et al., 2010). Images of Et uptake were analyzed with the ImageJ 
program (NIH software). For time-lapse fluorescence imaging, cells plated on glass coverslips were washed twice in HBSS. Then, cells were exposed to Locke's solution (containing $154 \mathrm{~mm} \mathrm{NaCl}, 5.4 \mathrm{~mm} \mathrm{KCl}, 2.3$ $\mathrm{mm} \mathrm{CaCl}_{2}, 5 \mathrm{~mm}$ HEPES, pH 7.4) with $5 \mu \mathrm{m}$ Et. Phase-contrast and fluorescence microscopy with time-lapse imaging were used to record cell appearance and fluorescence intensity changes in each condition as described previously (Retamal et al., 2007). Changes in slope were tested by regression lines fitted to points before and after treatments using the Excel program and mean values of slopes were compared using GraphPad Prism software.

Acute slices. For snapshot experiments, acute slices were incubated with $20 \mu \mathrm{M}$ Et for $5 \mathrm{~min}$ in a chamber with oxygenated $\left(95 \% \mathrm{O}_{2}\right.$ and $5 \%$ $\mathrm{CO}_{2}$ ) ACSF, $\mathrm{pH}$ 7.4. Then, they were washed five times for 2 min each with ACSF and fixed at room temperature with $2 \%$ paraformaldehyde for $30 \mathrm{~min}$, mounted in Fluoromount, and examined in a confocal laserscanning microscope (TBCS SP2; Leica). Stacks of consecutive confocal images taken with a $63 \times$ objective at $500 \mathrm{~nm}$ intervals were acquired sequentially with two lasers (argon, $488 \mathrm{~nm}$, and helium/neon, $543 \mathrm{~nm}$ ), and $Z$ projections were reconstructed using Leica confocal software. Dye uptake ratio was calculated as the subtraction $\left(F-F_{0}\right)$ between the fluorescence $(F)$ from respective cell ( $\sim 50$ cells per slice) and the background fluorescence $\left(F_{0}\right)$ measured where no labeled cells were detected. At least six fields were selected in every slice.

\section{Electrophysiology}

Coverslips containing cells were transferred to an experimental chamber mounted on the stage of an inverted microscope (Olympus IX-51; Olympus Optical). For whole-cell voltage-clamp experiments in microglia, and astrocytes, the bath solution contained the following (in $\mathrm{mm}$ ): 140 $\mathrm{NaCl}, 5.4 \mathrm{KCl}, 1 \mathrm{MgCl}_{2}, 1.8 \mathrm{CaCl}_{2}, 2 \mathrm{BaCl}_{2}, 10$ HEPES, pH 7.4. The pipette solution contained the following (in mM): $130 \mathrm{CsCl}, 10 \mathrm{AspNa}$, $0.26 \mathrm{CaCl}_{2}, 1 \mathrm{MgCl}_{2}, 2$ EGTA, 7 tetraethylammonium (TEA)-Cl, 5 HEPES, pH 7.2. For whole-cell experiments in neurons, bath solution contained the following (in mM): $120 \mathrm{NaCl}, 3 \mathrm{KCl}, 14$-aminopyridine, 1 $\mathrm{MgCl}_{2}, 2 \mathrm{CaCl}_{2}, 10$ TEA-Cl, $0.05 \mathrm{CdCl}_{2}, 0.01$ nifedipine, 0.001 TTX, 10 glucose, 10 HEPES, pH 7.4. The pipette solution had the same composition as the one used for whole-cell experiments in astrocytes and microglia. Patch pipettes were made from borosilicate glass capillaries using a Flaming/Brown micropipette puller (P-87; Sutter Instrument). The tip resistance was 5-10 $\mathrm{M} \Omega$ when filled with pipette solution. Currents were filtered at $1 \mathrm{kHz}$ and sampled at $5 \mathrm{kHz}$. Then, records were filtered with a digital low-pass filter of $0.5 \mathrm{kHz}$. Data acquisition and analysis were performed using pClamp 9 (Molecular Devices).

\section{Western blot analysis}

Cultures were rinsed twice with PBS, pH 7.4, and harvested by scraping with a rubber policeman in ice-cold solution containing protease and phosphatase inhibitors ( $1 \mathrm{~mm}$ orthovanadate, $10 \mathrm{~mm}$ $\alpha$-glycerophosphate) and complete miniprotease inhibitor (Roche Diagnostics). Proteins were measured in aliquots of cell lysates with the BioRad protein assay (Bio-Rad). Pelleted cells were resuspended in $40 \mu \mathrm{l}$ of the protease and phosphatase inhibitor solution, placed on ice, and lysed by sonication (ultrasonic cell disrupter; Microson; Ultrasons). Then, samples were stored at $-80^{\circ} \mathrm{C}$ or analyzed by immunoblotting. Aliquots of cell lysates or total biotinylated cell surface proteins were resuspended in a final concentration of $1 \times$ Laemmli's sample buffer, boiled for $5 \mathrm{~min}$, separated on $8 \%$ SDS-PAGE, and electrotransferred to nitrocellulose sheets. Nonspecific protein binding was blocked by incubation of nitrocellulose sheets in PBS-BLOTTO (5\% nonfat milk in PBS) for $30 \mathrm{~min}$, and then blots were incubated with primary antibody for $1 \mathrm{~h}$ at room temperature or overnight at $4^{\circ} \mathrm{C}$, followed by four $15 \mathrm{~min}$ PBS washes. Blots were incubated with goat anti-rabbit antibody conjugated to horseradish peroxidase. Immunoreactivity was detected by ECL detection using the SuperSignal kit (Pierce) according to instructions. Resulting immunoblot signals were scanned and transferred to a computer, and the densitometric analysis was performed with the Scion Image software. Furthermore, densitometric arbitrary units were normalized to the signal obtained from total protein measured with $\alpha$-tubulin.

\section{Cell surface biotinylation and quantification}

Cell cultures (90 mm dishes) were washed three times with ice-cold Hanks saline solution, $\mathrm{pH} 8.0$, and $3 \mathrm{ml}$ of sulfo-NHS-SS-biotin $(0.5$ $\mathrm{mg} / \mathrm{ml}$ ) was added followed by incubation for $30 \mathrm{~min}$ at $4^{\circ} \mathrm{C}$. Cells were washed three times with ice-cold saline plus $15 \mathrm{~mm}$ glycine, $\mathrm{pH} 8.0$, to block unreacted biotin. Then, they were harvested and an excess of immobilized NeutrAvidin was added ( $1 \mathrm{ml}$ of NeutrAvidin per $3 \mathrm{mg}$ of biotinylated protein), and the mixture was incubated for $1 \mathrm{~h}$ at $4^{\circ} \mathrm{C}$. Then, $1 \mathrm{ml}$ of washing buffer (saline solution, $\mathrm{pH} 7.2$, plus $0.1 \%$ SDS and $1 \%$ Nonidet P-40) was added; the mixture was centrifuged for $2 \mathrm{~min}$ at $14,000 \mathrm{rpm}$ at $4^{\circ} \mathrm{C}$ and the supernatant was removed and discarded. The pellet was resuspended in $40 \mu \mathrm{l}$ of saline solution, $\mathrm{pH} 2.8$, plus $0.1 \mathrm{M}$ glycine to release the proteins from the biotin, and the mixture was centrifuged at $14,000 \mathrm{rpm}$ for $2 \mathrm{~min}$ at $4^{\circ} \mathrm{C}$. The supernatant was placed in an Eppendorf tube $(1.5 \mathrm{ml})$, and the $\mathrm{pH}$ was adjusted immediately by adding $10 \mu \mathrm{l}$ of $1 \mathrm{M}$ Tris, $\mathrm{pH}$ 7.5. Relative levels of proteins were measured by Western analysis as described above. Resulting immunoblot signals were scanned and transferred to a computer, and the densitometric analysis was performed with the Scion Image software. Furthermore, densitometric arbitrary units were normalized to the signal obtained from total protein measured with Ponceau red.

\section{Immunofluorescence and confocal microscopy}

Cells grown on coverslips were fixed at room temperature with $2 \%$ paraformaldehyde for $30 \mathrm{~min}$ and then washed three times with PBS. They were incubated in $0.1 \mathrm{M}$ PBS-glycine, three times for $5 \mathrm{~min}$ each, and then in $0.1 \%$ PBS-Triton X-100 containing 10\% NGS for $30 \mathrm{~min}$. To identify microglia versus astrocytes, isolectin B4 and GFAP were used, respectively. Cells were incubated for $2 \mathrm{~h}$ at room temperature with anti-GFAP monoclonal antibody (IgG1; $1: 500$ ) diluted in $0.1 \%$ PBSTriton X-100 with 2\% NGS. After three rinses in 0.1\% PBS-Triton $\mathrm{X}-100$, cells were then incubated for $50 \mathrm{~min}$ at room temperature with both goat anti-mouse IgG Alexa Fluor 355 (1:1500) and isolectin GS-IB4 (1:100). To label Cx43, the anti-Cx43 monoclonal antibody (1:500) was incubated for $1 \mathrm{~h}$ at room temperature. After three washes, cells were incubated for $50 \mathrm{~min}$ at room temperature with goat anti-mouse IgG Alexa Fluor 488. Anti-MAP2 and NeuN monoclonal antibody (1:500 for both) were used to identify neurons. After several washes, coverslips were mounted in Fluoromount and examined with an upright microscope equipped with epifluorescence (Eclipse E800; Nikon). To visualize double immunostaining, a confocal laser-scanning microscope (TBCS SP2; Leica) was used. Stacks of consecutive confocal images were taken as mentioned above.

\section{Neuronal death quantification}

Neuronal cultures or acute slices were fixed in ethanol $(40 \%)$ at $4^{\circ} \mathrm{C}$ for 5 $\mathrm{min}$, and then were treated with detergent $(0.1 \%$ Triton X-100 in PBS) for $10 \mathrm{~min}$ and washed twice with distilled water. Preparations were incubated with $0.001 \%$ F-Jade in distilled water and gently shaken for 30 min in the dark as described previously (Schmuck and Kahl, 2009). The F-Jade was then removed, and cells or slices were washed and mounted in Fluoromount and examined with an upright microscope equipped with epifluorescence (Eclipse E800; Nikon) or visualized for double immunostaining in a confocal laser-scanning microscope (TBCS SP2; Leica).

\section{Apoptosis}

Cells were plated on 12-well dishes where the procedures for ApopTag Plus Rhodamine were done. In situ apoptosis detection kit was performed following the manufacturer's instructions for determination of apoptosis (Millipore). On termination of protocol, coverslips were placed on microscope slides and counterstained with DAPI $\left(4^{\prime}, 6-\right.$ diamidino-2-phenylindole) (Sigma-Aldrich) in PBS. Cells were visualized under an upright microscope equipped with epifluorescence (Eclipse E800; Nikon).

\section{Measurement of ATP and glutamate release}

Astrocytes were plated in multiwell culture trays $\left(10^{6}\right.$ cells $\cdot$ well ${ }^{-1} \cdot 0.5$ $\mathrm{ml}^{-1}$ ) and were used for experiments $48 \mathrm{~h}$ later. Extracellular ATP was measured by luciferin/luciferase bioluminescence assay kit (SigmaAldrich). Levels of extracellular glutamate were determined using an 

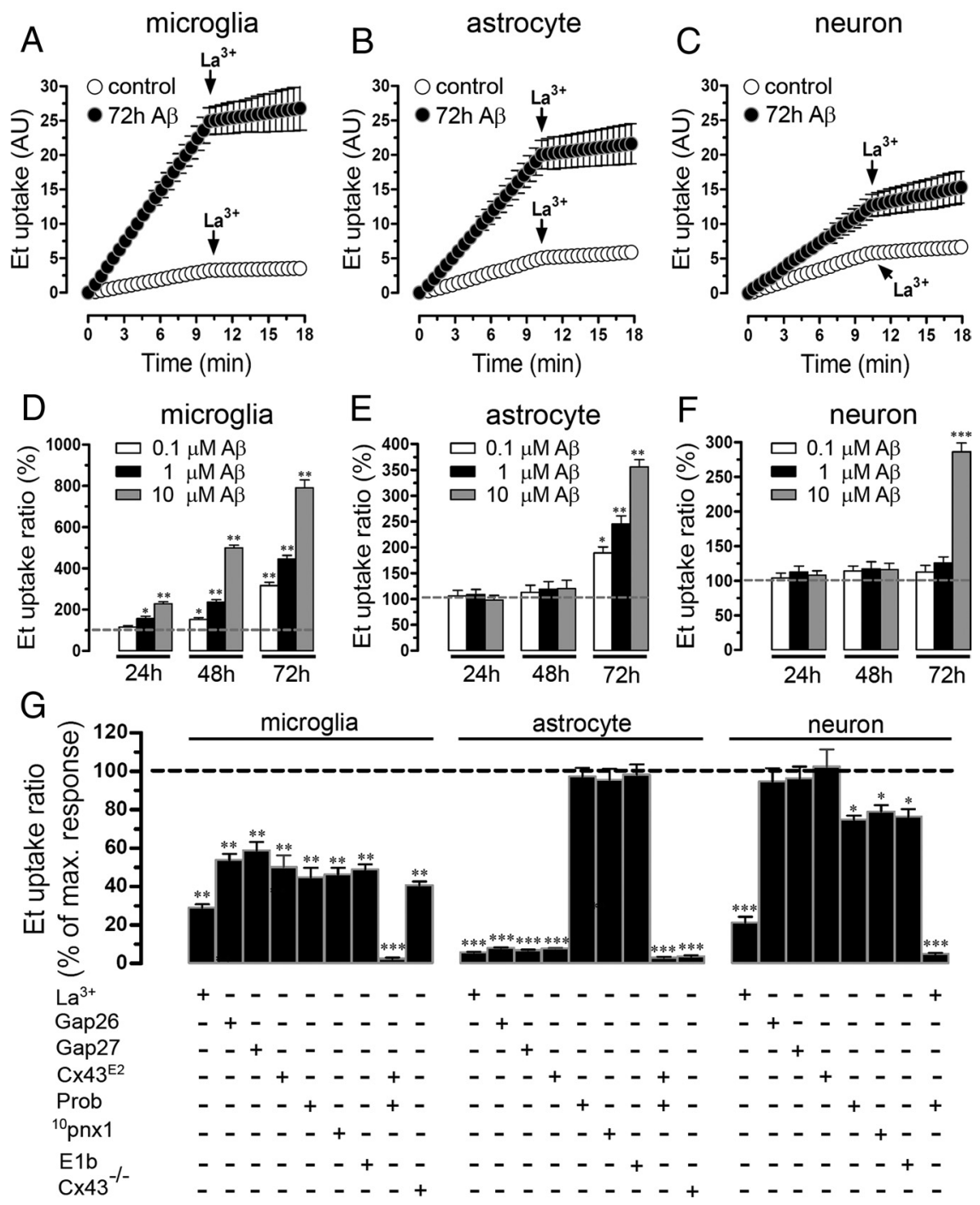

Figure 1. $A \beta_{25-35}$ increases the Et uptake in cultured microglia, astrocytes and neurons in a concentration- and timedependent manner. $\boldsymbol{A}-\boldsymbol{C}$, Time-lapse measurements of Et uptake in cultured mouse microglia $(\boldsymbol{A})$ and astrocytes $(\boldsymbol{B})$ and in enriched cultures of neurons $(\boldsymbol{C})$ under control conditions (white circles) or treated for $72 \mathrm{~h}$ with $10 \mu \mathrm{m} \mathrm{A} \beta_{25-35}$ (black circles). $\mathrm{La}^{3+}(200 \mu \mathrm{M})$, a connexin hemichannel blocker, applied at $\sim 10 \mathrm{~min}$ of Et uptake measurements decreased uptake. $\boldsymbol{D}-\boldsymbol{F}$, Averaged data normalized to control (dashed line) of Et uptake ratio of microglia $(\boldsymbol{D})$, astrocytes $(\boldsymbol{E})$, or neurons $(\boldsymbol{F})$ treated for 24 , 48, or $72 \mathrm{~h}$ with 0.1 (white bars), 1 (black bars), or $10 \mu \mathrm{M}$ (gray bars) $\mathrm{A} \beta_{25-35 .}{ }^{*} p<0.05$, ${ }^{* *} p<0.005$, and ${ }^{* * *} p<0.001$, treatments compared with respective controls. G, Averaged data normalized to the effect induced by $72 \mathrm{~h}$ treatment with $10 \mu \mathrm{m}$ $\mathrm{A} \beta_{25-35}$ on Et uptake ratio in microglia (left bars), astrocytes (middle bars), or neurons (right bars) exposed to the following Cx43 hemichannel blockers coapplied during dye uptake recording: $\mathrm{La}^{3+}(200 \mu \mathrm{M})$, Gap26 (200 $\left.\mu \mathrm{M}\right)$, Gap27 (200 $\left.\mu \mathrm{M}\right)$, and Cx43 ${ }^{\mathrm{E} 2}$; or exposed to blockers of Panx1 hemichannels: Prob $(500 \mu \mathrm{m}),{ }^{10}$ panx1 $(200 \mu \mathrm{m})$, and $\mathrm{E} 1 \mathrm{~b}(200 \mu \mathrm{M})$. Also shown is the Et uptake rate in microglia and astrocyte cultures of $\left(x 43^{-1-}\right.$ mice. ${ }^{*} p<0.05,{ }^{* *} p<0.005$, and ${ }^{* * *} p<0.001$, treatments compared with maximal response induced by $10 \mu \mathrm{m} \mathrm{A} \beta_{25-35}$. Averaged data were obtained from at least six independent experiments. Error bars indicate SEM.

enzyme-linked fluorimetric assay as described previously (Genever and Skerry, 2001). In the presence of glutamate dehydrogenase (GDH) and $\beta$-nicotinamide adenine dinucleotide phosphate $\left(\mathrm{NADP}^{+}\right)$, glutamate is oxidized to $\alpha$-ketoglutarate, yielding NADPH, which can be determined fluorimetrically (excitation and emission wavelengths of 355 and 460 $\mathrm{nm}$, respectively) for an indirect quantification of glutamate concentration. For each assay, standard curves were constructed by using known ATP and glutamate concentrations. The ATP and glutamate concentration in samples of extracellular medium were calculated from standard curves and referred to $10^{6}$ cells. The fraction of ATP or glutamate released by cells to the extracellular milieu was estimated by the difference between the concentration detected in the medium of cells under resting conditions and the concentration measured after stimulation in the presence or absence of hemichannel inhibitors.
Data analysis and statistics

For each data group, results are expressed as mean $\pm \mathrm{SE}$, and $n$ refers to the number of independent experiments. For statistical analysis, each treatment was compared with its respective control, and significance was determined using a one-way ANOVA followed in case of significance by Tukey's post hoc test. For multiple-group treatments, significance was determined using a two-way ANOVA followed in case of significance by Bonferroni's post hoc test.

\section{Results}

$\mathrm{A} \boldsymbol{\beta}_{25-35}$ increases hemichannel activity in microglia, astrocytes, and neurons Cellular activation and damage occur in brain cells treated with $\mathrm{A} \beta_{25-35}$ (Pike et al., 1995b; Block et al., 2007; Allaman et al., 2010), and activation of hemichannels has been recently shown to increase under proinflammatory conditions (Orellana et al., 2009) and play a critical role in astroglial death induced by hypoxia-reoxygenation in high glucose (Orellana et al., 2010). Therefore, we evaluated the effect of $\mathrm{A} \beta_{25-35}$ on hemichannel activity measured as Et ( $5 \mu \mathrm{M})$ uptake in primary cultures of microglia, astrocytes as well as in enriched cultures of neurons. As indicated by time-lapse measurements, under control conditions these three cell types showed a low basal Et uptake rate $(0.18 \pm$ $0.04,0.34 \pm 0.02$, and $0.28 \pm 0.03 \mathrm{AU} /$ min, respectively; $n=5$ ) (Fig. $1 A-C$ ), which was maintained in astrocytes and neurons after 24 or $48 \mathrm{~h}$ treatment with $0.1,1$, or $10 \mu \mathrm{M} \mathrm{A} \beta_{25-35}$ (Fig. $1 E, F$, respectively). However, microglia treated for $24 \mathrm{~h}$ with 1 or $10 \mu \mathrm{M} \mathrm{A} \beta_{25-35}$ presented an increased Et uptake ratio measured in snapshot experiments $(157.1 \pm 25.3$ and $228.2 \pm 22.9 \%$ compared with control, respectively; $n=5$ ) (Fig. $1 D$ ). In either microglia, astrocytes, or neurons treated for $72 \mathrm{~h}$ with $\mathrm{A} \beta_{25-35}$, the Et uptake was increased in a concentration-dependent manner and $10 \mu \mathrm{M} \mathrm{A} \beta_{25-35}$ was the tested concentration with the most prominent effect $(789.8 \pm 88.1,355.9 \pm 30.9$, and $285.9 \pm 28.8 \%$ compared with control, respectively; $n=5$ ) (Fig. $1 D-F)$. In all cell types, a peptide with the inverse sequence of $\mathrm{A} \beta_{25-35}$ domain, $\mathrm{A} \beta_{35-25}$, did not induce such effect (data not shown).

Because microglia, astrocytes, and neurons express enhanced connexin hemichannel activity in pathological conditions (Orellana et al., 2009), we applied connexin hemichannel blockers, $\mathrm{La}^{3+}$, or "Cx43 mimetic peptides," Gap26 or Gap27 (Evans and Leybaert, 2007), to determine the contribution of connexin hemichannels on Et cellular permeabilization induced by $10 \mu \mathrm{M}$ $\mathrm{A} \beta_{25-35}$ treatment for $72 \mathrm{~h}$. In "time-lapse" experiments, $\mathrm{La}^{3+}$ $(200 \mu \mathrm{M})$ greatly reduced the $\mathrm{A} \beta_{25-35}$-induced Et uptake in microglia (from $1.54 \pm 0.01$ to $0.26 \pm 0.05 \mathrm{AU} / \mathrm{min} ; n=5$ ) (Fig. 
$1 A$ ), astrocytes (from $1.19 \pm 0.01$ to $0.41 \pm 0.02 \mathrm{AU} / \mathrm{min} ; n=5$ ) (Fig. $1 \mathrm{~B}$ ), and neurons (from $0.82 \pm 0.02$ to $0.36 \pm 0.03 \mathrm{AU} / \mathrm{min}$; $n=5$ ) (Fig. 1C). Moreover, $\mathrm{La}^{3+}$, Gap27, or Gap26 (all at 200 $\mu \mathrm{M})$ reduced the maximal $\mathrm{A} \beta_{25-35}$-induced Et uptake in snapshot experiments in microglia (from 100 to $29.1 \pm 3.7 \%$; $58.9 \pm 9.5$ and $53.8 \pm 6.9 \%$, respectively; $n=5$ ) (Fig. $1 G$ ) and astrocytes (from 100 to $5.7 \pm 0.4 \% ; 6.9 \pm 0.6$ and $8.0 \pm 0.7 \%$, respectively; $n=5$ ) (Fig. 1G). Because it has been suggested that Gap27 or Gap26 are not specific in their action on $\mathrm{Cx} 43$ hemichannels (Wang et al., 2007), we used the $\mathrm{Cx} 43^{\mathrm{E} 2}$ antibody directed against the second loop of $\mathrm{Cx} 43$ that specifically blocks $\mathrm{Cx} 43$ hemichannels, but not gap junction channels (Siller-Jackson et al., 2008). $\mathrm{Cx} 43^{\mathrm{E} 2}$ (1:500) reduced the maximal $\mathrm{A} \beta_{25-35}$-induced Et uptake in snapshot experiments in microglia (from 100 to $50.2 \pm 10.3 \% ; n=5$ ) (Fig. $1 G$ ) and astrocytes (from 100 to $7.8 \pm 0.3 \% ; n=5$ ) (Fig. 1G). Thus, these results are in agreement with the data obtained with Gap26 and Gap27, suggesting that $\mathrm{Cx} 43$ hemichannels are the main contributors in the $\mathrm{A} \beta_{25-35}$-induced Et uptake in astrocytes and in part in microglia. In neurons, $\mathrm{La}^{3+}$, but neither Gap26, $\mathrm{Cx} 43^{\mathrm{E} 2}$, nor Gap27, blocked the $\mathrm{A} \beta_{25-35}$-induced Et uptake (Fig. $1 G$ ), suggesting that connexin hemichannels with a subunit composition different from Cx43 are partially responsible for the $A \beta_{25-35^{-}}$ induced Et uptake.

Since cultured microglia, astrocytes, and neurons express Panx1 (Huang et al., 2007; Shestopalov and Panchin, 2008; Iglesias et al., 2009), which is able to form functional hemichannels (Bao et al., 2004), we investigated the possible contribution of Panx1 hemichannels in the $\mathrm{A} \beta_{25-35}$-induced Et uptake. Two "Panx1 mimetic peptides" ( ${ }^{10}$ pnx1 and E1b; $200 \mu \mathrm{M}$ ) and probenecid $(500 \mu \mathrm{M})$, all blockers of Panx1 hemichannels (Pelegrin and Surprenant, 2006; Wang et al., 2007; Silverman et al., 2008), were used. Each compound reduced partially the maximal $\mathrm{A} \beta_{25-35^{-}}$ induced Et uptake in microglia (from 100 to $46.3 \pm 7.6 \%$; $48.9 \pm$ 6.0 and $44.9 \pm 10.8 \%$, respectively; $n=5$ ) (Fig. $1 G$ ) and neurons (from 100 to $79.1 \pm 7.1 \%$; $76.4 \pm 8.3$ and $74.8 \pm 4.9 \%$, respectively; $n=5)($ Fig. $1 G)$. However, in astrocytes these Panx1 blockers did not significantly inhibit the $\mathrm{A} \beta_{25-35}$-induced Et uptake (from 100 to $95.5 \pm 12.6 \%$; $98.2 \pm 11.7$ and $97.3 \pm 9.9 \%$, respectively; $n=5 ; p>0.1$ ) (Fig. 1G). The above findings suggest that, in astrocytes, Cx43 but not Panx1 hemichannels mediate the $\mathrm{A} \beta_{25-35}$-induced Et uptake. This interpretation was supported by the absence of $\mathrm{A} \beta_{25-35}$-induced hemichannel activation in astrocytes cultured from $\mathrm{Cx} 43^{-1-}$ mice $(3.82 \pm 0.7 \%$, compared with $100 \%$ of $\mathrm{A} \beta_{25-35}$ effect; $n=5$ ) (Fig. $1 G$ ). Moreover, the $\mathrm{A} \beta_{25-35^{-}}$ induced Et uptake was partially reduced in microglia from Cx43 ${ }^{-1-}$ mice ( $40.8 \pm 2.9 \%$, compared with $100 \%$ of $\mathrm{A} \beta_{25-35}$ effect; $n=5$ ) (Fig. $1 G$ ), suggesting that $\mathrm{A} \beta_{25-35}$-induced microglial permeabilization occurred partially through both $\mathrm{Cx} 43$ and Panx1 hemichannels. In neurons, a connexin hemichannel with a composition different from $\mathrm{Cx} 43$ seems to be the main contributor along with Panx1 hemichannels in the $\mathrm{A} \beta_{25-35}$-induced Et uptake. Importantly, acutely $10 \mu \mathrm{m}$ capsazepine did not block the $\mathrm{A} \beta_{25-35^{-}}$ induced Et uptake in all cell types (data not shown), ruling out the possible contribution of TRPV1 channels in this response.

\section{Cultured microglia, astrocytes, and neurons treated with $A \boldsymbol{\beta}_{25-35}$ present single hemichannel current events}

As an attempt to identify the membrane pathway through which $\mathrm{A} \beta_{25-35}$ increases the membrane permeability of microglia, astrocytes, or neurons, we used the voltage-clamp technique in the whole-cell configuration. Because the membrane potential of these cells under resting conditions is negative, we investigated
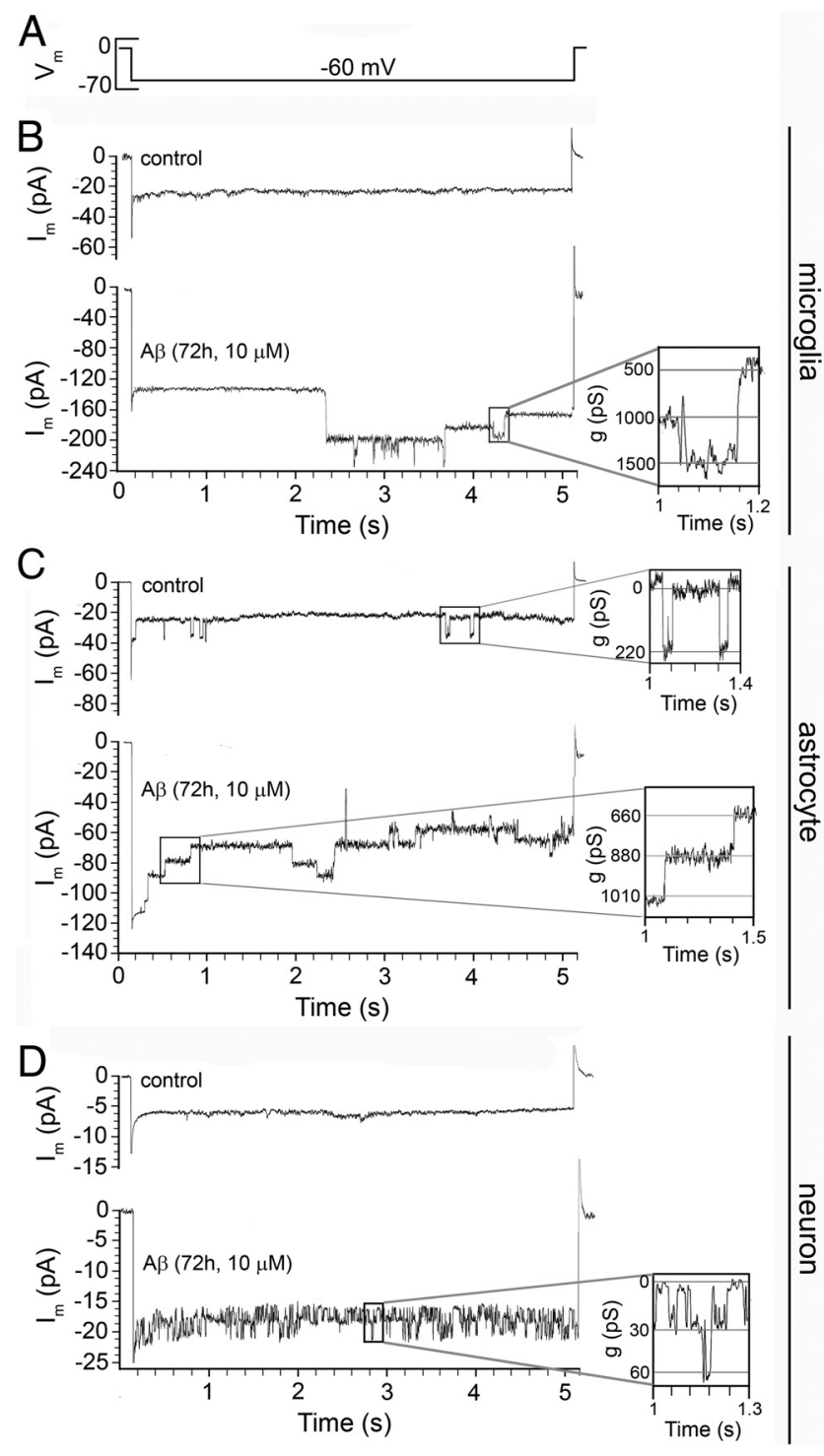

Figure 2. $\quad A \beta_{25-35}$ increases the number of hemichannel unitary current events in cultured microglia, astrocytes, and neurons. Membrane currents were measured in a whole-cell voltageclamp configuration $(\boldsymbol{A})$ using low-density cultures of microglia $(\boldsymbol{B})$, astrocytes $(\boldsymbol{C})$, or neurons (D) under control conditions or treated for $72 \mathrm{~h}$ with $10 \mu \mathrm{M} \mathrm{A} \beta_{25-35}$. $\boldsymbol{B}-\boldsymbol{D}$, Representative current traces elicited by $5 \mathrm{~s}$ of voltage steps from 0 to $-60 \mathrm{mV}$ and then back to $0 \mathrm{mV}$. The boxed regions on the right show conductance of $\sim 500(\boldsymbol{B}), \sim 220(\boldsymbol{C})$, and $\sim 30 \mathrm{pS}(\boldsymbol{D})$ with transitions between closed and open states, corresponding to unitary conductances of Panx1, Cx43, and Cx36 hemichannels, respectively.

the presence of hemichannel unitary events applying a voltage step from 0 to $-60 \mathrm{mV}$ and then back to $0 \mathrm{mV}$ (Fig. 2). In control astrocytes, unitary events were not detected in 12 cells (data not shown), but another 14 cells showed a few unitary current events (Fig. 2C), whereas in control microglia and neurons, unitary events were not detected in 11 and 15 cells, respectively (Fig. $2 B, D)$. In contrast, in all cell types treated with $10 \mu \mathrm{M} \mathrm{A} \beta_{25-35}$ for $72 \mathrm{~h}$, unitary current events were consistently observed (Fig. $2 B-$ $D)$. Point-by-point conversion of current to conductance values revealed unitary conductances of $507 \pm 15,217 \pm 8$, and $28 \pm 4$ pS for microglia (Fig. $2 B)(n=5)$, astrocytes (Fig. $2 C)(n=6)$, and neurons (Fig. $2 D)(n=5)$, respectively. These values are close to the expected unitary conductance of Panx1, Cx43, and Cx36 hemichannels, respectively (Bao et al., 2004; Sáez et al., 2005). When voltage ramps from -80 to $+80 \mathrm{mV}$ were applied 

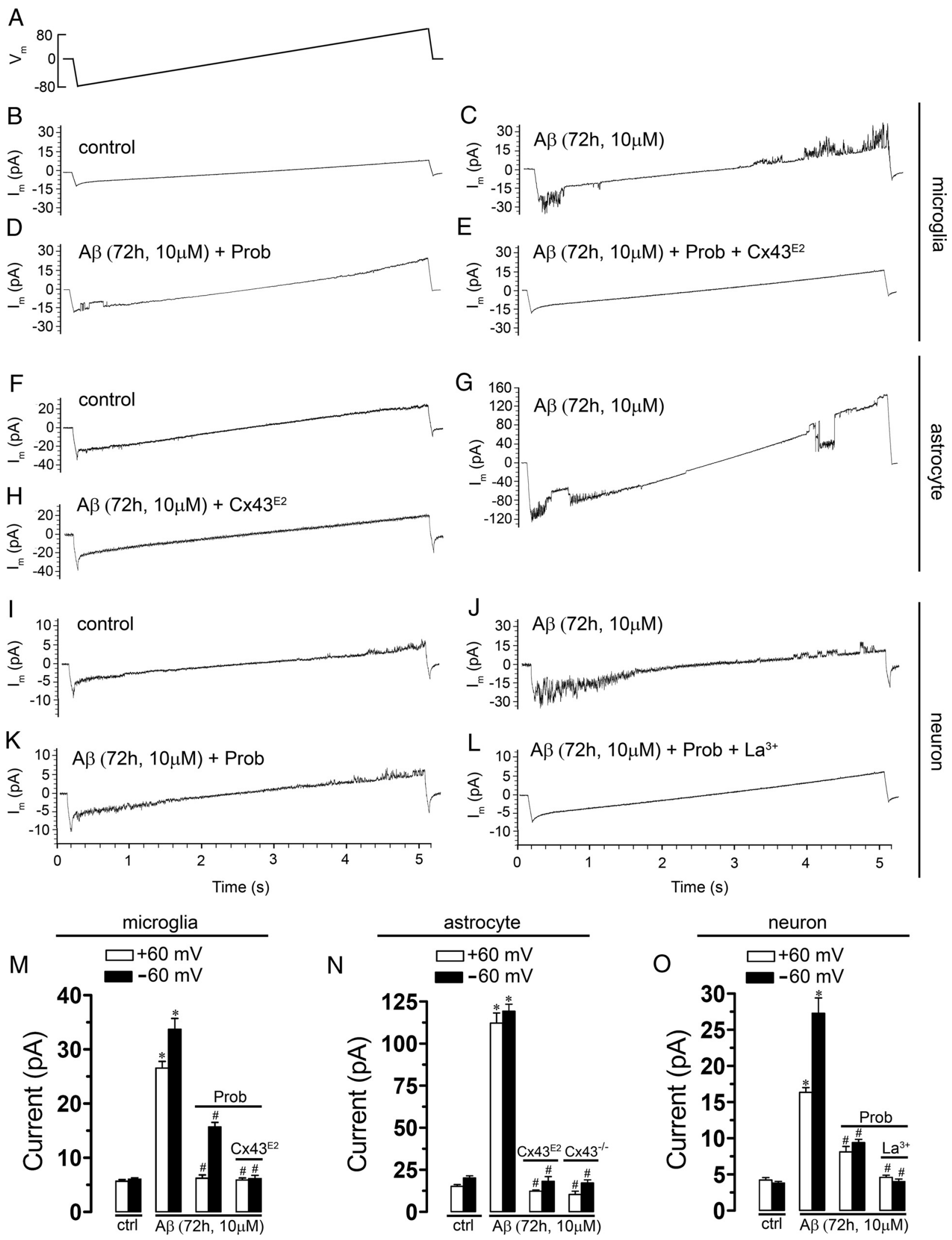

Figure 3. Currents at negative and positive potentials induced by $A \beta_{25-35}$ in microglia, astrocytes, and neurons are reduced in presence of hemichannel blockers. $A$, Voltage ramps from -80 to $+80 \mathrm{mV}$, $5 \mathrm{sin}$ duration, were applied. Each ramp was initiated and finished by a transition from 0 to -80 and +80 to $0 \mathrm{mV}$, respectively. Membrane currents were measured in whole-cell voltage-clamp configuration using low-density cultures of microglia $(\boldsymbol{B}-\boldsymbol{E})$, astrocytes $(\boldsymbol{F}-\boldsymbol{H})$, or neurons $(\boldsymbol{I}-\boldsymbol{L})$ under control conditions $(\boldsymbol{B}, \boldsymbol{F}, \boldsymbol{I})$ or treated for $72 \mathrm{~h}$ with $10 \mu \mathrm{mA} \boldsymbol{\beta}_{25-35}$ alone $(\boldsymbol{C}, \boldsymbol{G}, J)$. Additionally, probenecid $(200 \mu \mathrm{M}, \operatorname{Prob})$ was applied alone during current recordings $(\boldsymbol{D}, \boldsymbol{K})$ or in combination with $\mathrm{Cx} 4 \mathrm{E}^{\mathrm{E} 2}$ pretreatment $(\boldsymbol{E})$ or La ${ }^{3+}(200 \mu \mathrm{M})(\boldsymbol{L})$ in cells treated with $10 \mu \mathrm{m} \mathrm{A} \boldsymbol{\beta}_{25-35}$ for $72 \mathrm{~h}$. $\boldsymbol{M}-\mathbf{0}$, Averaged data normalized to the effect induced by $72 \mathrm{~h}$ treatment with $10 \mu \mathrm{MA} \beta_{25-35}$ on current events in microglia $(\boldsymbol{M})$, astrocytes $(\boldsymbol{N})$, or neurons $(\boldsymbol{O})$ exposed to Prob alone, Prob plus $C \times 43^{\mathrm{E} 2}$, and Prob plus $\mathrm{La}^{3+}$. In $\boldsymbol{M}$ and $\boldsymbol{N}$ are also shown total currents in microglia and astrocyte, respectively, obtained from $C \times 43^{-1-}$ mice. ${ }^{*} p<0.001$, treatments compared with response induced by $10 \mu \mathrm{M} A \beta_{25-35 ;} ; p<0.001$, inhibitory effect of blocker on the response induced by $10 \mu \mathrm{mA} \beta_{25-35}$. Averaged data were obtained from at least four independent experiments. Error bars indicate SEM. 

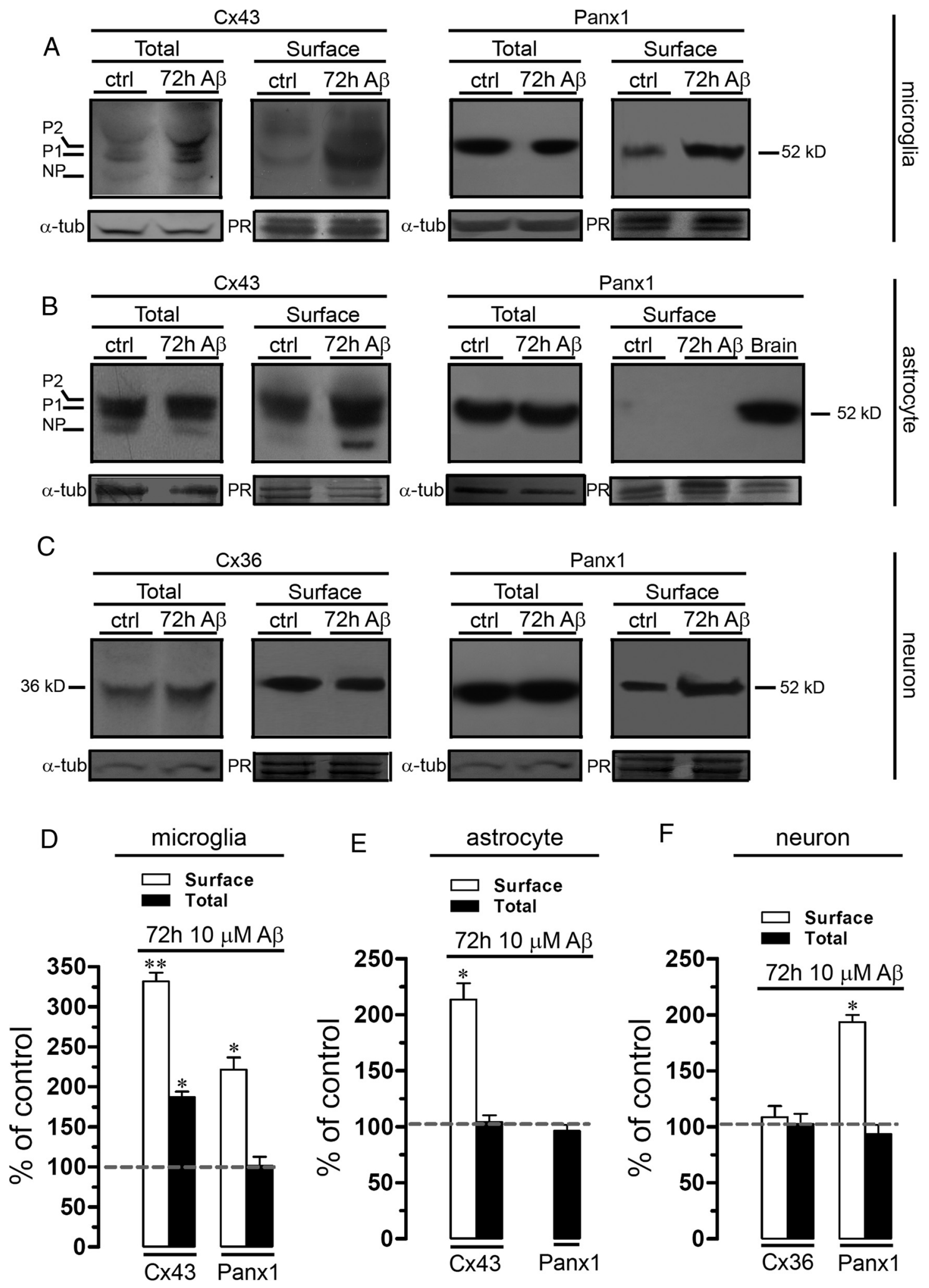

\section{잉}

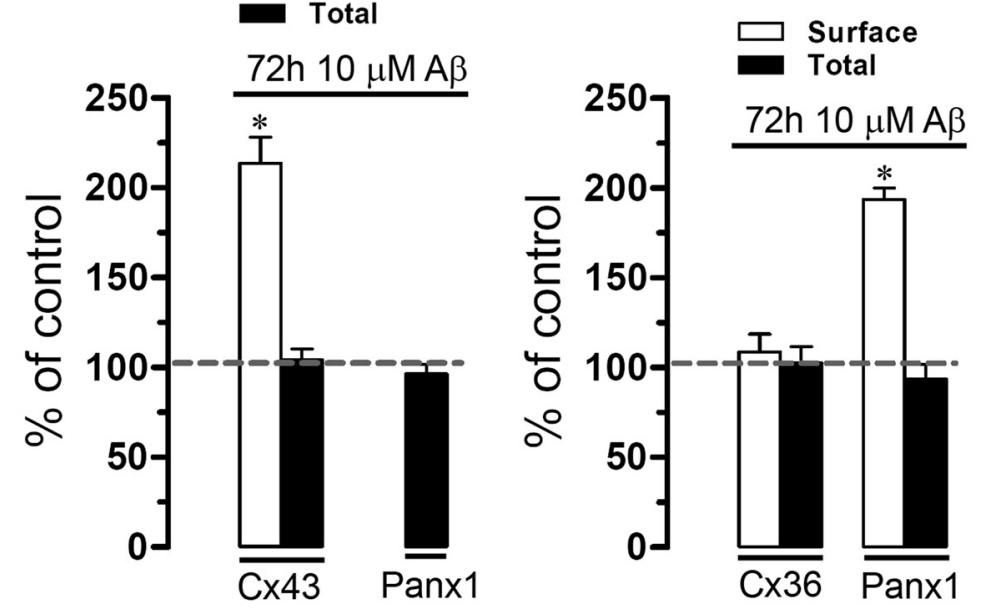

Figure 4. $A \beta_{25-35}$ increases the surface levels of $(x 43$ in microglia and astrocytes and Panx1 in microglia and neurons. Cultured microglia $(\boldsymbol{A})$, astrocytes $(\boldsymbol{B})$, or neurons $(\boldsymbol{C})$ were treated for $72 \mathrm{~h}$ with $10 \mu \mathrm{m} \mathrm{A} \beta_{25-35}$. A, Total and surface levels of $\mathrm{Cx} 43$ (left panel) and Panx1 (right panel) in microglia under control conditions (lane 1 ) or treated for $72 \mathrm{~h}$ with $10 \mu \mathrm{m} A \boldsymbol{\beta}_{25-35}$ alone (lane 2). $\boldsymbol{B}$, Total and surface levels of $\left(x 43\right.$ (left panel) and Panx 1 (right panel) present in astrocytes under control conditions (lane 1 ) or treated for $72 \mathrm{~h}$ with $10 \mu \mathrm{m} A \beta_{25-35}$ (lane 2 ). $C$, Total and surface levels of Cx36 (left panel) and Panx1 (right panel) present in neurons under control conditions (lane 1) or treated for $72 \mathrm{~h}$ with $10 \mu \mathrm{m} \mathrm{A} \beta_{25-35}$ (lane 2). The (x43 phosphorylated (P1-P2) and nonphosphorylated (NP) forms are indicated in the left of respective gel. Total levels of each analyzed protein were normalized according to the levels of $\alpha$-tubulin detected in each lane. Surface levels of each analyzed protein were normalized according to the total protein loaded as reveled by staining with Ponceau red (PR) in each lane. $D-F$, Quantitation of surface (white bars) and total (black bars) levels of $\left(x 43\right.$ and Panx 1 in microglia $(\boldsymbol{D})$ and astrocytes $(\boldsymbol{E})$ under control conditions or subjected to $72 \mathrm{~h}$ treatment with $10 \mu \mathrm{m} A \beta_{25-35}$. $\boldsymbol{F}, 0$ uantification of surface (white bars) and total (black bars) levels of $\left(x 36\right.$ and Panx1 in neurons under control conditions or subjected to $72 \mathrm{~h}$ treatment with $10 \mu \mathrm{m} A \beta_{25-35}$. Averaged data were obtained from at least three independent experiments. ${ }^{*} p<0.05,{ }^{* *} p<0.005$, compared with control. Error bars indicate SEM. 

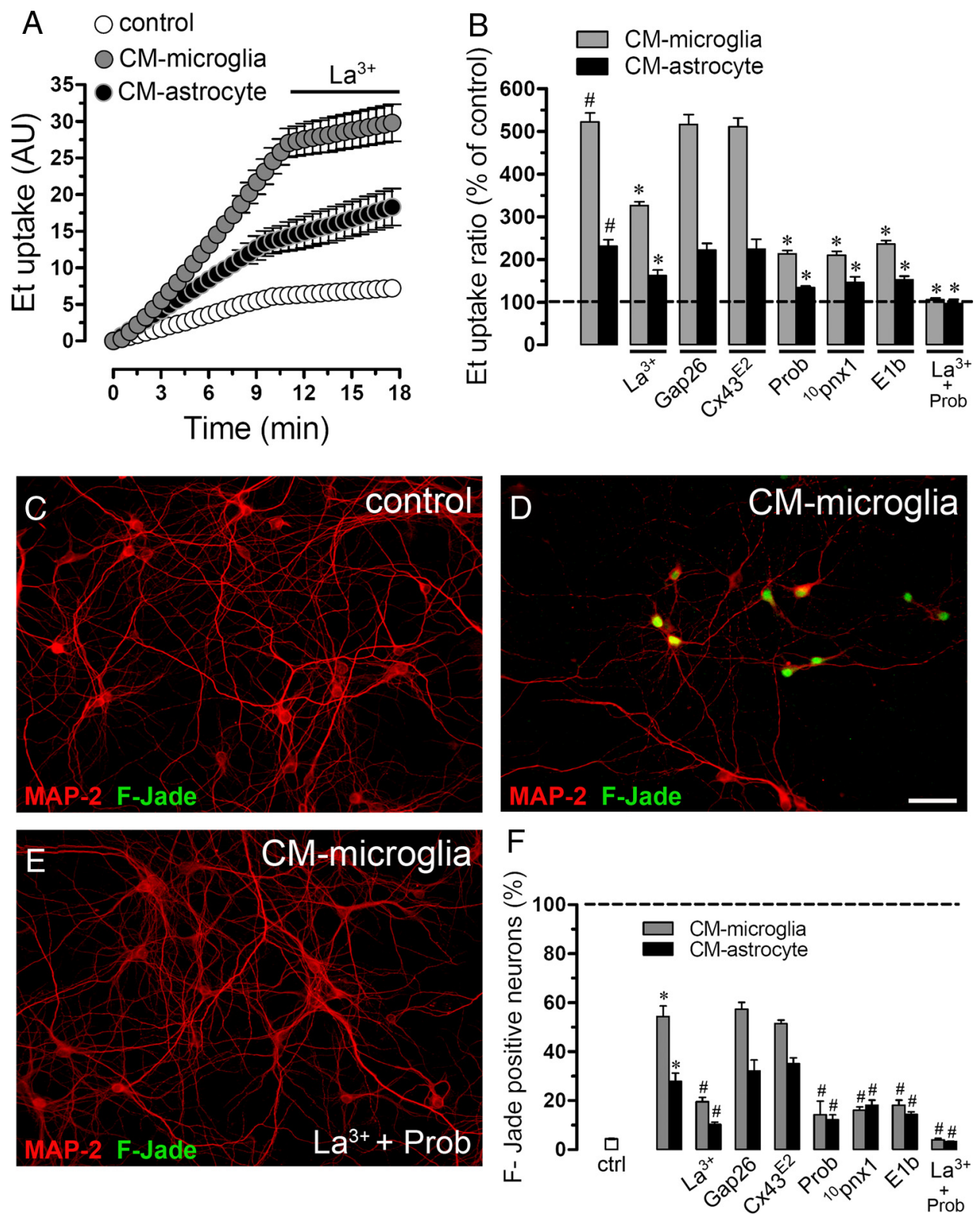

Figure 5. $A \beta_{25-35}$-treated astrocytes and microglia promote neuronal Et uptake via hemichannels and neuronal death. $A$, Time-lapse measurements of Et uptake in enriched-cultures of neurons under control conditions (white circles) or treated for $3 \mathrm{~h}$ with CM harvested from microglia (gray circles) or astrocytes (black circles) incubated with $10 \mu \mathrm{M} A \beta_{25-35}$ by $72 \mathrm{~h} . \boldsymbol{B}$, Averaged data normalized to control (dashed line) of Et uptake rate of neurons treated for $3 \mathrm{~h}$ with CM-microglia (gray bars) or CM-astrocyte (black bars). Also shown is the effect of the following blockers applied

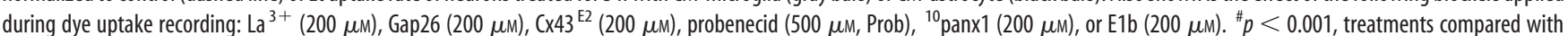
respective controls; ${ }^{*} p<0.05$, effect of each blocker compared with the treatment with the respective conditioned medium. $\boldsymbol{C}-\boldsymbol{E}$, Representative immunofluorescence images depicting MAP-2 (red) and F-Jade (green) labeling of neurons under control conditions (C), treated for $3 \mathrm{~h}$ with CM-microglia alone (D) or with CM-microglia plus La ${ }^{3+}$ (200 $\left.\mu \mathrm{M}\right)$ plus Prob (500 $\left.\mu \mathrm{M}\right)(\boldsymbol{E}) . \boldsymbol{F}$, Averaged data normalized to control (dashed line) of neuronal survival after $3 \mathrm{~h}$ with CM-microglia (gray bars) or CM-astrocyte (black bars). It is shown the effect of La ${ }^{3+}(200 \mu \mathrm{M})$, Gap26 (200 $\left.\mu \mathrm{M}\right), \mathrm{Cx} 43^{\mathrm{E} 2}$ $(200 \mu \mathrm{M}), \operatorname{Prob}(500 \mu \mathrm{M}),{ }^{10}$ panx1 $(200 \mu \mathrm{M})$, or E1b $(200 \mu \mathrm{M}) .{ }^{\#} p<0.001$, treatments compared with respective controls. ${ }^{*} p<0.05$, effect of each blocker compared with treatment with the respective conditioned medium. Averaged data are obtained from at least five independent experiments. Scale bar, $180 \mu \mathrm{m}$. Error bars indicate SEM.

using whole-cell patch clamp, a few unitary events were detected in $\sim 20 \%$ of total control microglia, astrocytes, and neurons (data not shown) ( $n=13, n=15$, and $n=14$, respectively), whereas the rest of recorded cells did not present unitary events (Fig. $3 B, F, I$, respectively). Notably, in microglia and astrocytes treated with $10 \mu \mathrm{M} \mathrm{A} \beta_{25-35}$ for $72 \mathrm{~h}$, the number of unitary current events was greatly increased at either negative (at $-60 \mathrm{mV}$ from $6.0 \pm$ 0.8 to $33.7 \pm 4.4 \mathrm{pA}$ and from $20.2 \pm 3.2$ to $119.3 \pm 9.2 \mathrm{pA}$, respectively; $n=14$ and 16) or positive potentials (at $+60 \mathrm{mV}$ from $5.7 \pm 0.8$ to $26.6 \pm 2.7 \mathrm{pA}$ and from $15.2 \pm 2.6$ to $112.2 \pm$ $13.4 \mathrm{pA}$, respectively; $n=14$ and 16 ) (Fig. $3 C, G, M, N$ ). In con- trast, the occurrence of unitary current events in neurons was mainly increased at negative potentials (at $-60 \mathrm{mV}$ from $3.8 \pm$ 0.6 to $27.2 \pm 4.2 \mathrm{pA} ; n=12$ ) and a little less at positive potentials (at $+60 \mathrm{mV}$ from $4.2 \pm 0.8$ to $16.3 \pm 1.3 \mathrm{pA} ; n=12$ ) (Fig. $3 \mathrm{~J}, O)$. To elucidate the involvement of hemichannels in the $\mathrm{A} \beta_{25-35^{-}}$ induced current transitions, we used probenecid $(200 \mu \mathrm{M})$, $\mathrm{Cx} 43^{\mathrm{E} 2}(1: 500)$, and $\mathrm{La}^{3+}(200 \mu \mathrm{M})$. The Panx1 hemichannel blocker, probenecid, partially inhibited the $\mathrm{A} \beta_{25-35}$-induced current transitions in microglia and neurons at negative (at $-60 \mathrm{mV}$ from $33.7 \pm 4.4$ to $15.7 \pm 1.7 \mathrm{pA}$ and from $27.2 \pm 4.2$ to $9.4 \pm 0.8$ $\mathrm{pA}$, respectively; $n=10$ and 11 ) and positive potentials (at +60 
$\mathrm{mV}$ from $26.6 \pm 2.7$ to $6.2 \pm 1.2 \mathrm{pA}$ and from $16.3 \pm 1.3$ to $8.1 \pm$ $1.3 \mathrm{pA}$, respectively; $n=10$ and 11 ) (Fig. $3 D, K, M, O$ ). Moreover, the $\mathrm{Cx} 43$ hemichannel blocker, $\mathrm{Cx} 43^{\mathrm{E} 2}$, in combination with probenecid completely inhibited the $A \beta_{25-35}$-induced current transitions in microglia (at $-60 \mathrm{mV}$ from $33.7 \pm 4.4$ to $6.2 \pm 1.1$ $\mathrm{pA}$ and at $+60 \mathrm{mV}$ from $26.6 \pm 2.7$ to $5.9 \pm 0.6 \mathrm{pA} ; n=13$ ) (Fig. $3 E, M)$, suggesting that both Panxl and $\mathrm{Cx} 43$ hemichannels are involved. A general connexin hemichannel blocker, $\mathrm{La}^{3+}$, in combination with probenecid completely inhibited the $\mathrm{A} \beta_{25-35^{-}}$ induced current transitions in neurons (at $-60 \mathrm{mV}$ from $27.2 \pm$ 4.2 to $4 \pm 0.6 \mathrm{pA}$ and at $+60 \mathrm{mV}$ from $16.3 \pm 1.3$ to $4.6 \pm 0.5 \mathrm{pA}$; $n=10$ ) (Fig. $3 \mathrm{~L}, O$ ), suggesting the involvement of Panx1 hemichannels and an unknown connexin hemichannel, possibly formed by $\mathrm{Cx} 36$ according to the unitary events recorded (Fig. $2 D$ ). This is in agreement with the fact that, in neuronal cultures, we observed that the $\mathrm{A} \beta$-induced Et uptake was partially inhibited either by $\mathrm{La}^{3+}$ and probenecid (also with ${ }^{10}$ panx1) in each neuron studied, indicating that they likely express both Cx36 and Panx1. In contrast, only the use of $\mathrm{Cx} 43^{\mathrm{E} 2}$ was sufficient to inhibit completely the $\mathrm{A} \beta_{25-35}$-induced currents in astrocytes (at -60 $\mathrm{mV}$ from $119.2 \pm 9.3$ to $18.2 \pm 4.7 \mathrm{pA}$ and at $+60 \mathrm{mV}$ from $112.2 \pm 13.5$ to $12.5 \pm 1.3 \mathrm{pA} ; n=12)($ Fig. $3 H, N)$, suggesting as it was shown before with the Et uptake experiments (Fig. $1 G$ ) that $\mathrm{Cx} 43$ hemichannels are the main contributors in this astroglial response. In agreement with this statement, $\mathrm{A} \beta_{25-35}$ did not induce single hemichannel currents in astrocytes obtained from $\mathrm{Cx} 43^{-1-}$ mice (at $-60 \mathrm{mV}, 17.2 \pm 3.1 \mathrm{pA}$, and at $+60 \mathrm{mV}$, $10.3 \pm 3.3 \mathrm{pA} ; n=9)($ Fig. $3 N)$.

\section{$\mathrm{A} \boldsymbol{\beta}_{25-35}$ increases the surface levels of $\mathrm{Cx} 43$ in microglia and astrocytes, and the surface levels of Panx1 in microglia and neurons}

Because previous studies have associated astroglial hemichannelmediated dye uptake with increased surface levels of hemichannels (Orellana et al., 2010), we tested whether $A \beta_{25-35}$ affects the surface level expression of $\mathrm{Cx} 43$ and Panx1 in microglia and astrocytes and of Cx36 and Panx1 in neurons. The total level of $\mathrm{Cx} 43$ expression is increased in microglia subjected to proinflammatory conditions [tumor necrosis factor- $\alpha$ (TNF- $\alpha$ ) and interferon- $\gamma($ IFN- $\gamma$ )] (Eugenín et al., 2003), but up to now there is no evidence of $\mathrm{Cx} 43$ surface levels in microglia. Here, we found that total and surface levels of $\mathrm{Cx} 43$ were increased in microglia treated with $10 \mu \mathrm{M} \mathrm{A} \beta_{25-35}$ for $72 \mathrm{~h}$ compared with control (187.1 \pm 6.9 and $331.6 \pm 18.8 \%$, respectively; $n=3 ; p<0.05$ ) (Fig. $4 A, D$ ). In addition, surface levels, but not total levels, of Panx1 were increased under the above treatment in microglia $(221.4 \pm 26.3 \% ; n=3 ; p<0.05)$ (Fig. $4 A, D$ ).

Surface $\mathrm{Cx} 43$ levels were increased in astrocytes treated for $72 \mathrm{~h}$ with $10 \mu \mathrm{M} \mathrm{A} \beta_{25-35}$ compared with control (213.5 $\pm 25.1 \%$; $n=3 ; p<0.05$ ) (Fig. $4 B, E$ ). Interestingly, whereas Panx1 was detected in total cell homogenates, no surface Panx 1 was found in control astrocytes or subjected to $\mathrm{A} \beta_{25-35}$ treatment (Fig. $4 B, E$ ). Indeed, under all conditions described above, total levels of astroglial $\mathrm{Cx} 43$ and Panx1 were not affected (Fig. 4B,E).

Since $\mathrm{Cx} 36$ and Panx1 have been detected in neurons (Huang et al., 2007; Schock et al., 2008), we investigated their expression levels in neurons. Total and surface Cx36 levels in neurons under control conditions or those subjected to $\mathrm{A} \beta_{25-35}$ treatment were similar (Fig. 4C,F). However, surface Panx1 levels were increased in neurons treated for $72 \mathrm{~h}$ with $10 \mu \mathrm{M} \mathrm{A} \beta_{25-35}$ compared with control (193.6 $\pm 10.7 \% ; n=3 ; p<0.05)$ (Fig. $4 C, F)$, whereas total levels were not affected (Fig. $4 C, F$ ).
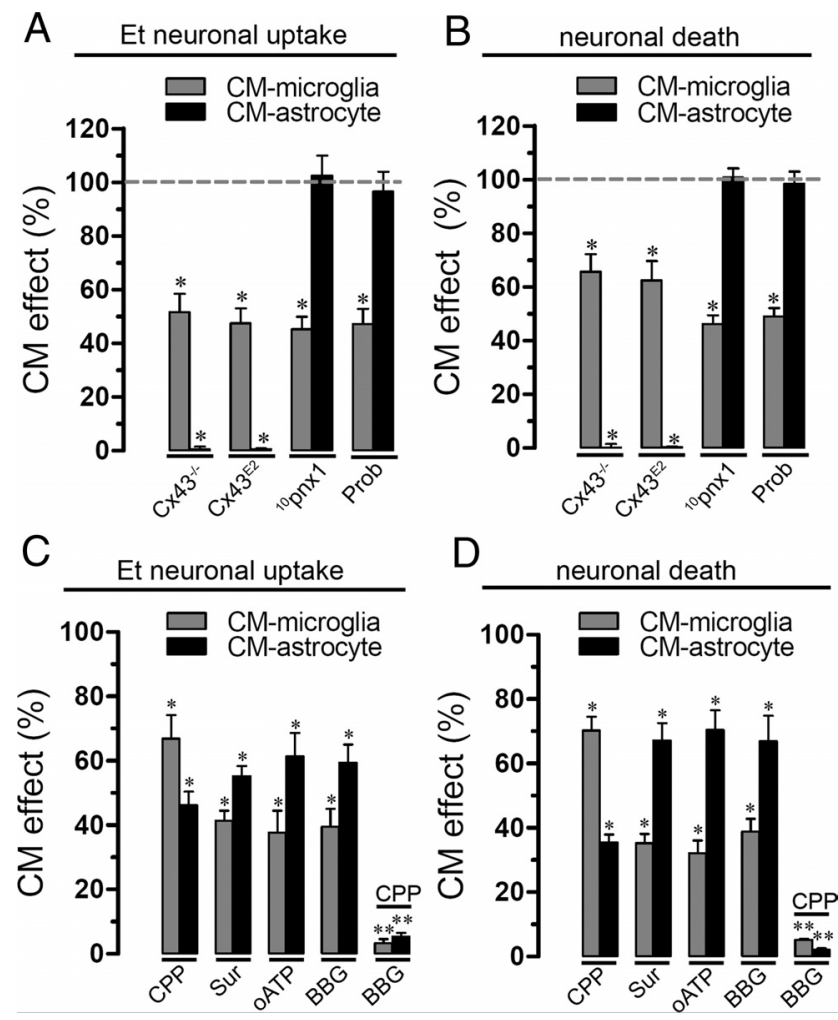

Figure 6. Death and opening of neuronal hemichannel induced by conditioned medium from $A \beta_{25-35}$-treated glia is a hemichannel and NMDA/P2 receptor-dependent process. $A$, Et uptake ratio of neurons normalized to the effect of $3 \mathrm{~h}$ of incubation of CM harvested from $A \beta_{25-35}(10 \mu \mathrm{m})$-treated microglia (gray bars) or astrocytes (black bars) of $\left(x 43^{-1-}\right.$ mice or CM made in the presence of $C \times 43^{\mathrm{E} 2},{ }^{10}$ panx1 $(200 \mu \mathrm{M})$, or Prob $(200 \mu \mathrm{M})$. $\boldsymbol{B}$, F-Jade labeling normalized to the effect of $3 \mathrm{~h}$ of incubation of $C M$ harvested from $A \beta_{25-35}(10 \mu \mathrm{m})$-treated microglia (gray bars) or astrocytes (black bars) of $\mathrm{C} \times 43^{-1-}$ mice or $\mathrm{CM}$ made in the presence of Cx43 ${ }^{\mathrm{E} 2},{ }^{10}$ panx1 $(200 \mu \mathrm{m})$, or Prob $(200 \mu \mathrm{m}) .^{*} p<0.05$, compared with $100 \%$ of CM effect. $C$, Averaged data normalized to the effect of $3 \mathrm{~h}$ of incubation of $\mathrm{CM}$ harvested from $\mathrm{A} \beta_{25-35}$ (10 $\mu \mathrm{M}$ )-treated microglia (gray bars) or astrocytes (black bars) on Et uptake ratio of neurons cotreated with $20 \mu \mathrm{m}$ CPP (NMDA receptor blocker), $200 \mu \mathrm{m}$ suramin (Sur) (P2 receptor blocker), $200 \mu \mathrm{m}$ oATP (P2X receptor blocker), or $10 \mu \mathrm{m}$ BBG (P2X 7 receptor blocker) during CM incubation. $D$, Averaged data normalized to the effect of $3 \mathrm{~h}$ incubation with CM from microglia (gray bars) or astrocytes (black bars) on F-Jade labeling of neurons cotreated with $20 \mu \mathrm{M}$ CPP and 200 $\mu \mathrm{M}$ suramin, $200 \mu \mathrm{M}$ oATP, or $10 \mu \mathrm{M}$ BBG during CM incubation. ${ }^{*} p<0.05,{ }^{* *} p<0.005$, compared with $100 \%$ of CM effect. Averaged data are obtained from four independent experiments. Error bars indicate SEM.

\section{Glial hemichannels activated by $\mathrm{A} \boldsymbol{\beta}_{25-35}$ induce neuronal} death through increased activity of neuronal hemichannels Because hemichannel-mediated release of molecules occurs in activated microglia, promoting neuronal damage (Takeuchi et al., 2006), we examined whether the increase in hemichannel activity induced by $\mathrm{A} \beta_{25-35}$ in microglia and astrocytes could affect hemichannel opening in neurons through a paracrine pathway. Therefore, enriched neuronal cultures were incubated for $3 \mathrm{~h}$ with $\mathrm{CM}$ of microglia or astrocytes treated with $10 \mu \mathrm{M}$ $\mathrm{A} \beta_{25-35}$ for $72 \mathrm{~h}$. Neurons treated for $3 \mathrm{~h}$ with $\mathrm{CM}$ of microglia or astrocytes presented a prominent increase in Et uptake rate (1.23 \pm 0.11 and $0.55 \pm 0.08 \mathrm{AU} / \mathrm{min}$, respectively; compared with control, $0.28 \pm 0.03 \mathrm{AU} / \mathrm{min} ; n=4$ ) (Fig. $5 \mathrm{~A}$ ) and Et uptake ratio measured in snapshot experiments $(521.9 \pm 47.2$ and $230.8 \pm 34.8 \%$, respectively, compared with control; $n=5$ ) (Fig. $5 B$ ). As a control, $10 \mu \mathrm{M} \mathrm{A} \beta_{25-35}$ used alone on enriched neuronal cultures had no effect on Et uptake (data not shown) indicating that for this concentration and time of application the peptide contained in the CM had no effect per se. To elucidate the con- 

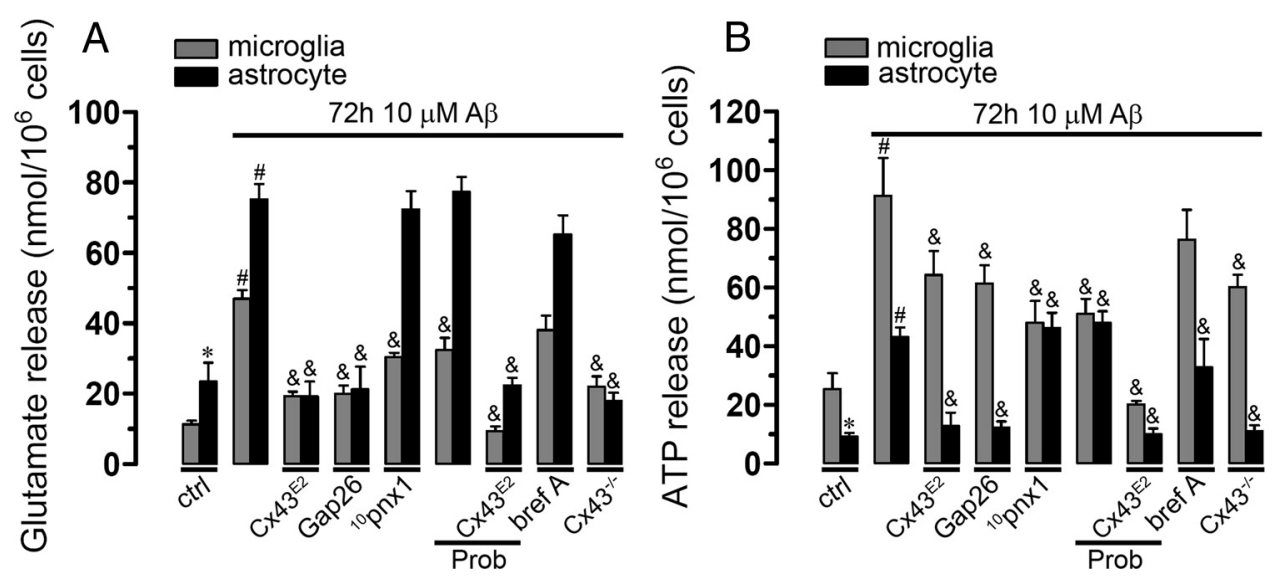

Figure 7. $A \beta_{25-35}$-treated microglia and astrocytes exhibit increase glutamate and ATP release. $\boldsymbol{A}, \boldsymbol{B}$, Glutamate $(\boldsymbol{A})$ and ATP $(\boldsymbol{B})$ concentration in CM by microglia (gray bars) or astrocytes (black bars) under control conditions or after treatment with $10 \mu \mathrm{mA} \beta_{25-35}$ for $72 \mathrm{~h}$. In some experiments, $\mathrm{Cx}_{3} \mathrm{E}^{\mathrm{E} 2}, 200 \mu \mathrm{m}$ Gap26, $200 \mu \mathrm{M}{ }^{10} \mathrm{panx} 1,500 \mu \mathrm{m}$ Prob, and $10 \mu \mathrm{m}$ brefeldin A were coapplied with $\mathrm{A} \beta_{25-35}$. Also shown are data obtained in astrocytes of $\mathrm{C} \times 43^{-1-}$ mice subjected to the same protocols mentioned above. Averaged data were obtained from three independent experiments. ${ }^{*} p<0.05$, microglial versus astroglial glutamate and ATP concentrations under control conditions; ${ }^{*} p<0.05 ;{ }^{*} A \beta_{25-35}$ treatment compared with control; ${ }^{*} p<0.05$, effects of blocker compared with $A \beta_{25-35}$ treatment. Glutamate and ATP release via hemichannels can be estimated by the difference in concentration measured before and after blockade of hemichannels. Error bars indicate SEM.
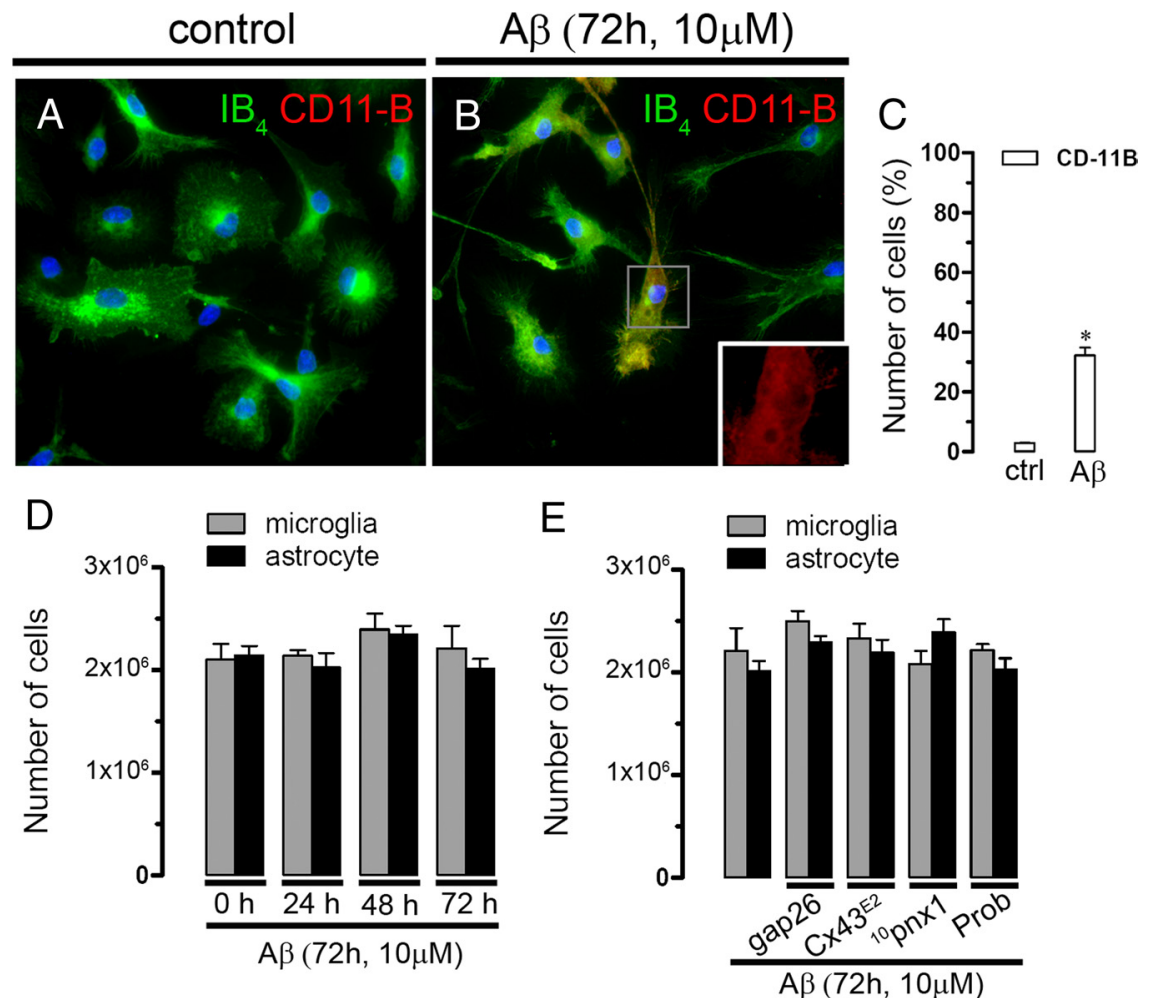

Figure 8. Cell proliferation is not affected by $A \beta_{25-35}$ and hemichannel blockers. $A, B$, Representative immunofluorescence images depicting isolectin GS-IB4 (green) and CD-11b (red) immunolabeling in microglial cultures under control conditions $(\boldsymbol{A})$ or after $72 \mathrm{~h}$ treatment with $10 \mu \mathrm{m} \mathrm{A} \beta_{25-35}(\boldsymbol{B})$. C, Quantification of the total number per field of CD-11B positive microglia under control conditions or treated by $72 \mathrm{~h}$ with $\mathrm{A} \beta_{25-35}(10 \mu \mathrm{M}) .{ }^{*} p<0.05$; compared with control. Averaged data obtained from four independent experiments. Scale bar, $20 \mu \mathrm{m}$. D, Proliferation of microglia (gray bars) and astrocytes (black bars) untreated ( $0 \mathrm{~h}$ of treatment) or treated for several time periods with $10 \mu \mathrm{M} \mathrm{A} \beta_{25-35}$. E, Proliferation of microglia (gray bars) and astrocytes (black bars) treated for $72 \mathrm{~h}$ with $10 \mu \mathrm{m} \mathrm{A} \beta_{25-35}$. In some experiments, $200 \mu \mathrm{m}$ Gap26, $\mathrm{CX} 43^{\mathrm{E} 2}, 200 \mu \mathrm{M}{ }^{10}$ panx1, $500 \mu \mathrm{m}$ Prob were coapplied with $\mathrm{A} \beta_{25-35}$. Error bars indicate SEM.

tribution of connexin and/or Panx1 hemichannels in the CMinduced Et uptake on neurons, we used $\mathrm{La}^{3+}$, Gap26, $\mathrm{Cx} 43^{\mathrm{E} 2}$, probenecid, ${ }^{10} \mathrm{pnx} 1$, or E1b to block the response. In time-lapse experiments, $\mathrm{La}^{3+}$ greatly reduced the neuronal Et uptake induced by CM from microglia or astrocytes $(0.32 \pm 0.02$ and
$0.35 \pm 0.04 \mathrm{AU} / \mathrm{min}$, respectively; $n=5$ ) (Fig. 5A). Similar results were obtained with $\mathrm{La}^{3+}$ in snapshot experiments (Fig. $5 B)$, whereas probenecid, ${ }^{10} \mathrm{pnx} 1$, and E1b partially reduced the neuronal Et uptake rate induced by CM from microglia $(212.8 \pm 18.3,209.7 \pm 20.2$, and $235.9 \pm$ $19.0 \%$, respectively, compared with control; $n=5)$ or astrocytes (134.3 \pm 7.2 , $146.1 \pm 29.2$, and $152.1 \pm 19.3 \%$, respectively, compared with control; $n=5$ ) (Fig. $5 B)$. However, neither Gap26 nor $\mathrm{Cx} 43^{\mathrm{E} 2}$ affected the CM-induced Et uptake on neurons (Fig. 5B). Importantly, CM from untreated microglia or astrocytes did not affect the neuronal dye uptake (data not shown). All these findings suggest that Panxl hemichannels and a putative connexin hemichannel, possibly composed of Cx36 (Fig. 1D), are the main contributors in the Et neuronal uptake induced by $\mathrm{CM}$ from microglia or astrocytes.

Furthermore, we investigated whether opening of neuronal hemichannels induced by CM could promote neuronal death. Under control conditions, most 12-d-old neurons were not labeled with F-Jade $(4.4 \pm 0.6 \%$ of total neurons; $n=$ 5) (Fig. 5C,F), a marker of neurodegeneration and neuronal death (Noraberg et al., 1999; Schmuck and Kahl, 2009). However, after $3 \mathrm{~h}$ treatment with CM from microglia or astrocytes, a prominent increase in neuronal death was observed $(54.3 \pm 9.5$ and $27.8 \pm 7.5 \%$ of total neurons, respectively; $n=5$ ) (Fig. $5 D, F)$. $\mathrm{La}^{3+}$, probenecid, ${ }^{10} \mathrm{pnx} 1$, and E1b greatly reduced neuronal death induced by CM from microglia (19.6 \pm $3.8,14.2 \pm 12.3,16.1 \pm 3$, and $18.2 \pm 4.4 \%$ of total cells, respectively; $n=5)$ or astrocytes $(10.2 \pm 2,12.1 \pm 4.4,18.2 \pm 4.2$, and $14.3 \pm 2.1 \%$ of total cells, respectively; $n=5$ ) (Fig. $5 F$ ). Interest- 
ingly, neither Gap26 nor $\mathrm{Cx} 43^{\mathrm{E} 2}$ affected the percentage of neuronal death induced by CM from astrocytes or microglia (Fig. $5 F$ ). These observations indicate that neuronal death induced by $\mathrm{CM}$ from $\mathrm{A} \beta_{25-35^{-}}$ treated microglia or astrocytes mainly proceeds through the activation of neuronal Panx1 and connexin hemichannels not sensitive to Gap26 or $\mathrm{Cx} 43^{\mathrm{E} 2}$. More importantly, both dye uptake and cell death did not occur in neurons incubated with $\mathrm{CM}$ from $\mathrm{A} \beta_{25-35}$-treated $\mathrm{Cx} 43^{-1-}$ astrocytes (Fig. $6 A, B$ ). This observation also confirms that the amount of $A \beta_{25-35}$ contained in the $\mathrm{CM}$ and its time of incubation $(3 \mathrm{~h})$ is not involved in neuronal death but it is rather a product released by $\mathrm{A} \beta$-treated microglia or astrocytes. Moreover, when CM from microglia was made in the presence of ${ }^{10} \mathrm{pnx} 1$ or probenecid, both neuronal death and neuronal Et uptake were less prominent compared with the effect induced by $\mathrm{CM}$ from microglia made in the absence of these blockers (from 100 to $46.2 \pm 3.1$ and $48.9 \pm 3.8$ or $45.2 \pm 4.6$ or $47.2 \pm 5.6 \%$, respectively; $n=4$ ) (Fig. $6 A, B$ ). Partial reduction in death and Et uptake were also observed in neurons incubated with $\mathrm{CM}$ from $\mathrm{C} \times 43^{-1-}$ microglia (from 100 to $65.6 \pm$ 6.4 and $51.6 \pm 6.7 \%$, respectively; $n=$ 4) (Fig. 6A,B), which implies the involvement of $\mathrm{Cx} 43$ hemichannels along with Panx1 hemichannels. Finally, both neuronal Et uptake and death induced by $\mathrm{CM}$ from microglia or astrocytes were partially blocked by the NMDA receptor blocker: 3-(2-carboxypiperazin4-yl)propyl-1-phosphonic acid (CPP) (from 100 to $66.9 \pm 7.2$ and $70.2 \pm 4.3$ or $46.1 \pm 4.2$ and $35.4 \pm 2.4 \%$, respectively; $n=$ 3 ) or the $\mathrm{P} 2 \mathrm{X}_{7}$ receptor blockers: suramin (from 100 to $41.3 \pm 3.2$ and $35.1 \pm 2.9$ or $55.2 \pm 3.1$ and $67.2 \pm 5.3 \%$, respectively; $n=$ 4), oxidized ATP (oATP) (from 100 to $37.5 \pm 6.8$ and $61.3 \pm 7.3$ or $32.1 \pm 3.9$ and $70.4 \pm 6.1 \%$, respectively; $n=3$ ), and brilliant blue G (BBG) (from 100 to $39.5 \pm 5.7$ and $59.3 \pm 5.6$ or $38.9 \pm$ 3.7 and $66.9 \pm 7.3 \%$, respectively; $n=3$ ) (Fig. $6 C, D$ ). Importantly, almost all neuronal Et uptake and death induced by CM from microglia or astrocytes were inhibited when both CPP and BBG were used in combination (from 100 to $3.3 \pm 1.3$ and $5.3 \pm$ 1.2 or $5.2 \pm 0.3$ and $2 \pm 0.5 \%$, respectively; $n=3$ ) (Fig. $6 C, D$ ). The above data suggest that hemichannel opening and death in neurons was attributable to release of glutamate and/or ATP from $\mathrm{A} \beta_{25-35}$-treated microglia and astrocytes and that glial $\mathrm{Cx} 43$ and/or Panx1 hemichannels might be key pathways involved in this process. To elucidate the possible role of glutamate and ATP in this response, we measured the concentration of these molecules in the CMs from astrocytes or microglia. Under control conditions, CM from astrocytes contained higher glutamate concentration than CM from microglia $\left(23.4 \pm 5.3 \mathrm{nmol} / 10^{6}\right.$ cells and $11.3 \pm 1 \mathrm{nmol} / 10^{6}$ cells, respectively; $n=3$ ) (Fig. $7 A$ ), whereas the CM from microglia higher ATP concentration than $\mathrm{CM}$ from astrocytes $\left(23.4 \pm 5.3 \mathrm{nmol} / 10^{6}\right.$ cells and $11.3 \pm 1$ $\mathrm{nmol} / 10^{6}$ cells, respectively; $n=3$ ) (Fig. $7 B$ ). As expected, treat-
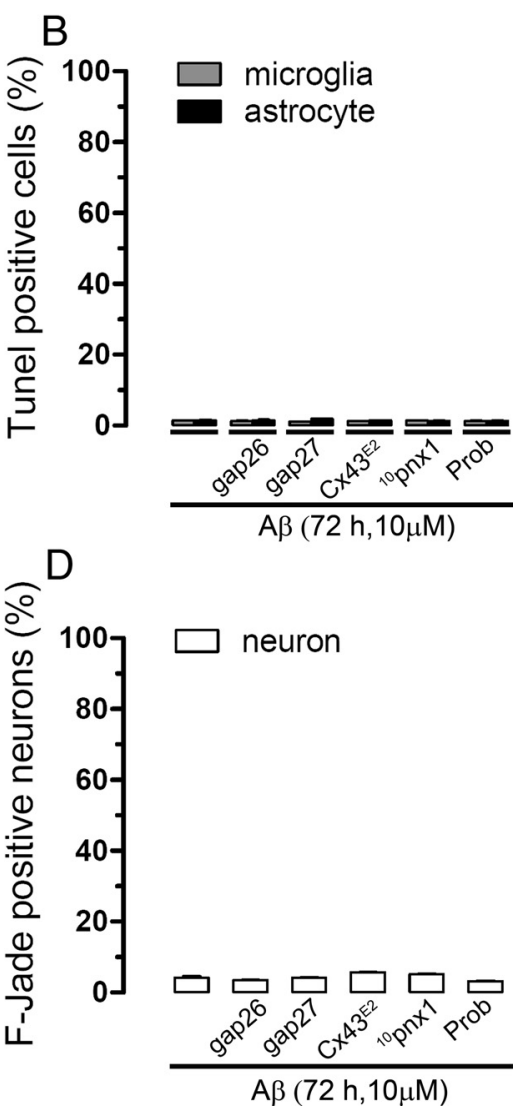

Figure 9. $\mathrm{A} \beta_{25-35}$ reduces cell viability only at long period of exposure. $\boldsymbol{A}$, Percentage comparing total cells of terminal ( cells of TUNEL-positive microglia (gray bars) or astrocytes (black bars) treated for $72 \mathrm{~h}$ with $10 \mu \mathrm{mA} \beta_{25-35}$. In some experiments, 200 $\mu$ M Gap26, $200 \mu \mathrm{M}$ Gap27, Cx43 ${ }^{\mathrm{E}}$, $200 \mu \mathrm{M}$ 10 panx1, $500 \mu \mathrm{m}$ Prob were coapplied with $A \beta_{25-35}$. C and $\boldsymbol{D}$ are similar experiments to $\boldsymbol{A}$ and $\boldsymbol{B}$, respectively, showing neuronal death evaluated with F-Jade. Averaged data were obtained from three independent experiments. ${ }^{*} p<0.05$; compared with control. Error bars indicate SEM.

ment with $10 \mu \mathrm{M} \mathrm{A} \beta_{25-35}$ for $72 \mathrm{~h}$ increased the glutamate and ATP concentration both in CM from astrocytes $(75.2 \pm 4.3$ $\mathrm{nmol} / 10^{6}$ cells and $43.1 \pm 3.1 \mathrm{nmol} / 10^{6}$, respectively; $\left.n=5\right)$ and microglia $\left(47.0 \pm 2.3 \mathrm{nmol} / 10^{6}\right.$ cells and $91.2 \pm 12.9 \mathrm{nmol} / 10^{6}$, respectively; $n=5$ ) (Fig. $7 A, B$ ). Moreover, treatment with $\mathrm{Cx} 43^{\mathrm{E} 2}$ and Gap26 blocked completely the $\mathrm{A} \beta_{25-35}$-induced increase in glutamate $\left(19.2 \pm 4.2 \mathrm{nmol} / 10^{6}\right.$ cells and $21.5 \pm 6.4 \mathrm{nmol} / 10^{6}$, respectively; $n=5)$ and ATP $\left(12.8 \pm 4.6 \mathrm{nmol} / 10^{6}\right.$ cells and $12.2 \pm$ $2.1 \mathrm{nmol} / 10^{6}$, respectively; $n=5$ ) in CM from astrocytes. Whereas in microglia, $\mathrm{Cx} 43^{\mathrm{E} 2}$ only partially inhibited the $\mathrm{A} \beta_{25-35}$-induced increase in glutamate $\left(19.3 \pm 1.3 \mathrm{nmol} / 10^{6}\right.$ cells and $20 \pm 2.3 \mathrm{nmol} /$ $10^{6}$, respectively; $\left.n=4\right)$ and ATP $\left(64.2 \pm 8.2 \mathrm{nmol} / 10^{6}\right.$ cells and $61.3 \pm 6.2 \mathrm{nmol} / 10^{6}$, respectively; $n=4$ ) in CM from microglia (Fig. $7 A, B)$. Similarly, ${ }^{10} \mathrm{pnx} 1$ and probenecid partially blocked the $\mathrm{A} \beta_{25}$ 35 -induced increase in the release of glutamate $\left(30.3 \pm 1.2 \mathrm{nmol} / 10^{6}\right.$ cells and $32.5 \pm 3.4 \mathrm{nmol} / 10^{6}$, respectively; $\left.n=4\right)$ and ATP ( $48 \pm$ $7.4 \mathrm{nmol} / 10^{6}$ cells and $51.4 \pm 5.1 \mathrm{nmol} / 10^{6}$, respectively; $\left.n=4\right)$ in $\mathrm{CM}$ of microglia. However, this response was completely inhibited by probenecid plus $\mathrm{Cx} 43^{\mathrm{E} 2}\left(9.3 \pm 1.3 \mathrm{nmol} / 10^{6}\right.$ cells and $20.1 \pm 1.2$ $\mathrm{nmol} / 10^{6}$, respectively; $n=4$ ) (Fig. $7 A, B$ ). The above data suggest that the $\mathrm{A} \beta_{25-35}$-induced release of glutamate and ATP in astrocytes occurs via $\mathrm{Cx} 43$ hemichannels and through both $\mathrm{Cx} 43$ and Panx1 hemichannels in microglia. Accordingly, total and partial reduction in the $\mathrm{A} \beta_{25-35}$-induced release of glutamate and ATP were observed in Cx43 $3^{-I-}$ astrocytes $\left(18 \pm 2.3 \mathrm{nmol} / 10^{6}\right.$ cells and $11 \pm 2.1 \mathrm{nmol} /$ 

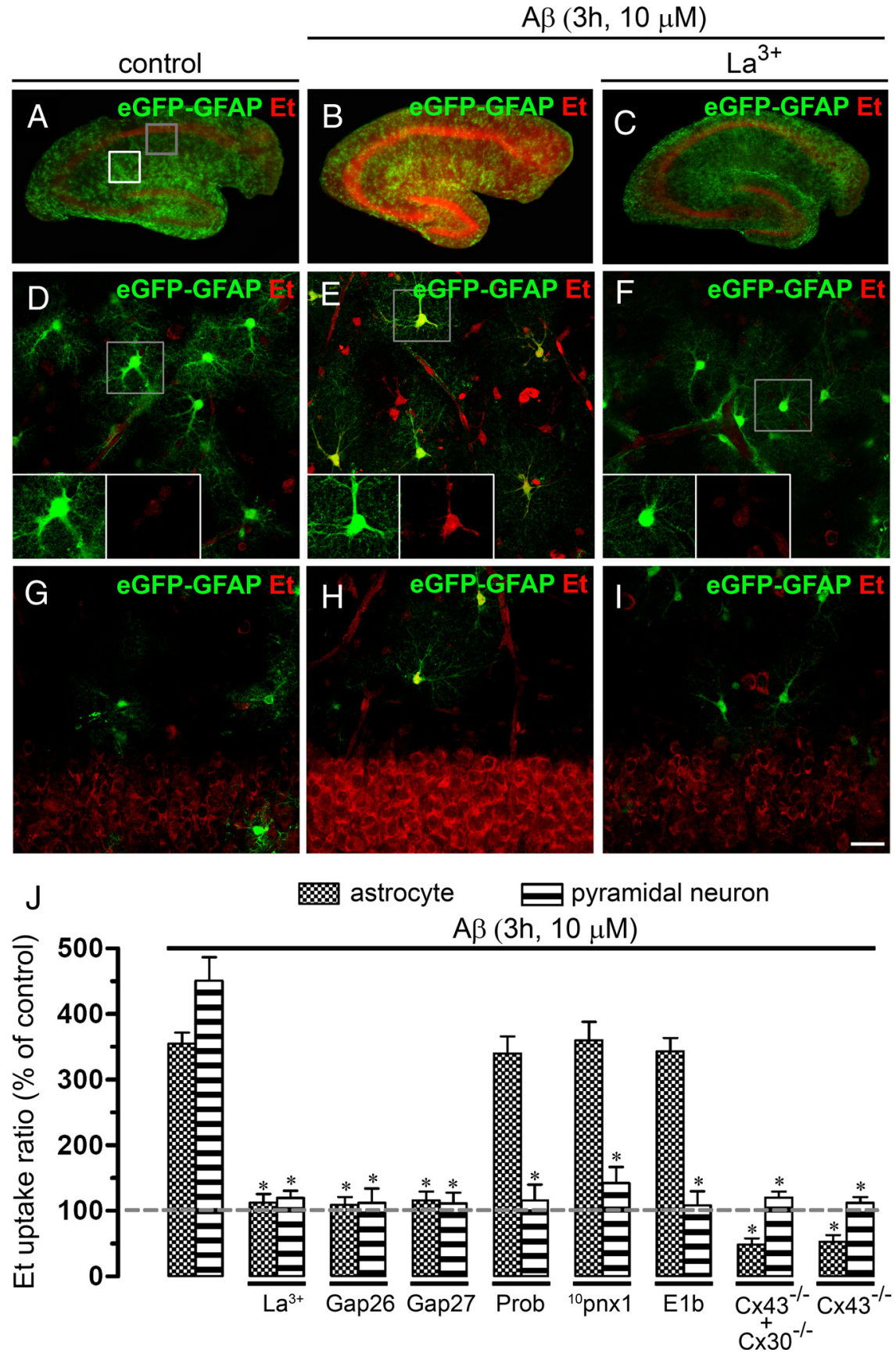

Figure 10. $A \beta_{25-35}$ increases the Et uptake in astrocytes and neurons of acute hippocampal slices. $A-I$, Representative images of acute hippocampal brain slices made from eGFP-GFAP transgenic mice showing eGFP-GFAP (green) and Et (red) uptake under control conditions $(\boldsymbol{A})$, treated for $3 \mathrm{~h}$ with $10 \mu \mathrm{m} \mathrm{A} \beta_{25-35}$ alone $(\boldsymbol{B})$ or $A \beta_{25-35}$ plus $200 \mu \mathrm{m} \mathrm{La}{ }^{3+}(\boldsymbol{C})$. D-F, Representative images of Et (red) uptake by hippocampal eGFP-GFAP astrocytes (green) under control conditions (D), treated for $3 \mathrm{~h}$ with $10 \mu \mathrm{m} \mathrm{A} \beta_{25-35}$ alone $(\boldsymbol{E})$, or $\mathrm{A} \beta_{25-35}$ plus $200 \mu \mathrm{m} \mathrm{La}{ }^{3+}(\boldsymbol{F})$ applied during the dye uptake measurements. Images of hippocampal astrocytes were taken from the zone depicted by the white square in $\boldsymbol{A}$. The respective bottom insets of representative astrocytes with staining for Et and eGFP-GFAP are also shown in $\boldsymbol{D}-\boldsymbol{F}$. G-I, Representative images of Et (red) uptake by hippocampal pyramidal neurons under control conditions (G), treated for $3 \mathrm{~h}$ with $10 \mu \mathrm{m}$ $\mathrm{A} \beta_{25-35}$ alone $(\boldsymbol{H})$, or plus $200 \mu \mathrm{M} \mathrm{La}{ }^{3+}(\boldsymbol{I})$. Images of pyramidal neurons were taken from the zone depicted by the gray square in $\boldsymbol{A}$ and then inverted for more clarity. $\boldsymbol{J}$, Averaged data normalized to control (dashed line) of Et uptake rate of hippocampal astrocytes (gray bars) or pyramidal neurons (striped bars) treated with $A \beta_{25-35}(10 \mu \mathrm{m} ; 3 \mathrm{~h})$ or treated with $\mathrm{A} \beta_{25-35}$ plus the following blockers applied during dye uptake recording: La ${ }^{3+}$ (200 $\left.\mu \mathrm{M}\right)$, Gap26 (200 $\left.\mu \mathrm{M}\right)$, Gap27 (200 $\mu \mathrm{M})$, Prob $(500 \mu \mathrm{M}),{ }^{10}$ panx1 $(200 \mu \mathrm{M})$, or E1b $(200 \mu \mathrm{M})$. Also shown is the Et uptake ratio in hippocampal astrocytes of

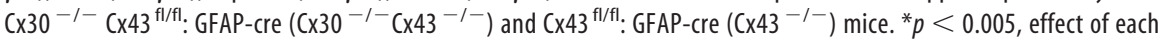
blocker compared with the respective effect induced by $10 \mu \mathrm{MA} \beta_{25-35}$ for $3 \mathrm{~h}$. Averaged data are obtained from six independent experiments. Scale bar: $\boldsymbol{A}-\boldsymbol{C}, 2 \mathrm{~mm} ; \boldsymbol{D}-\boldsymbol{I}, 50 \mu \mathrm{m}$. Error bars indicate SEM.
$10^{6}$, respectively; $n=3$ ) and microglia $\left(22 \pm 3 \mathrm{nmol} / 10^{6} \mathrm{cells}\right.$ and $60.1 \pm 4.3 \mathrm{nmol} /$ $10^{6}$, respectively; $n=3$ ), respectively (Fig. $7 A, B)$. In addition, inhibition of vesicular transport by $10 \mu \mathrm{m}$ brefeldin A induced only a slight reduction in the $\mathrm{A} \beta_{25-35}$-induced increase in glutamate and ATP in CM from microglia $\left(38.1 \pm 4.1 \mathrm{nmol} / 10^{6}\right.$ cells and $76.2 \pm 10.2 \mathrm{nmol} / 10^{6}$ cells, respectively; $n=$ $3)$ and astrocytes $\left(65.3 \pm 5.3 \mathrm{nmol} / 10^{6}\right.$ cells and $32.9 \pm 9.5 \mathrm{nmol} / 10^{6}$ cells, respectively; $n=3$ ), suggesting that the main pathway of glutamate and ATP release is via hemichannels. Within the time periods evaluated, $\mathrm{A} \beta_{25-35}$ did not change cell proliferation and viability (Figs. $8 D, 9 A-C$ ). Similarly, proliferation and cell viability were not affected by the hemichannel blockers used (Figs. 8E, 9B-D).

$\mathrm{A} \boldsymbol{\beta}_{25-35}$ activates hemichannels in astrocytes and neurons in acute hippocampal slices

To evaluate the $\mathrm{A} \beta_{25-35}$ effects on the cellular hemichannel activity of a more integrated system, we investigated whether $\mathrm{A} \beta_{25-35}$ affects the Et uptake in astrocytes and neurons studied in acute hippocampal slices. The Et uptake was evaluated in snapshot experiments in eGFP-GFAPpositive astrocytes of control hippocampal slices or after treatment for several time periods with $10 \mu \mathrm{M} \mathrm{A} \beta_{25-35}$. No evident changes in Et uptake compared with control were observed in astrocytes or neurons from hippocampal slices incubated for time periods $<3 \mathrm{~h}$ (data not shown). However, at $3 \mathrm{~h}$ treatment with $10 \mu \mathrm{M} \mathrm{A} \beta_{25-35}$ a prominent increase in Et uptake in eGFP-GFAP-positive astrocytes was evident $(354.8 \pm 45.9 \%$ compared with control; $n=6$ ) (Fig. $10 D, E, J$ ) and pyramidal neurons from the CA1 region $(450.8 \pm 94.9 \%$ compared with control; $n=6$ ) (Fig. $10 G, H, J)$. The $\mathrm{A} \beta_{25-35^{-}}$ induced Et uptake was blocked with $\mathrm{La}^{3+}$, Gap26, and Gap27 (all at $200 \mu \mathrm{M}$ ) in astrocytes $(112.8 \pm 34.1,109.5 \pm 22.9$, and $115.8 \pm 26.9 \%$ compared with control, respectively; $n=4$ ) (Fig. 10J) and neurons $(119.8 \pm 29.0,112.1 \pm 43.7$, and $111.3 \pm 32.4 \%$ compared with control, respectively; $n=4)($ Fig. $10 J)$. In contrast, probenecid, ${ }^{10} \mathrm{pnx} 1$, and E1b blocked the $\mathrm{A} \beta_{25-35}$-induced Et uptake in pyramidal neurons $(115.9 \pm 54.1,142.2 \pm 55.0$, and $108.1 \pm 49.0 \%$ compared with control, respectively; $n=4)($ Fig. $10 \mathrm{~J})$, but not in astrocytes $(339.9 \pm 58.3,359.7 \pm 63.8$, and $343.1 \pm 45.9 \%$ compared with control, respectively; $n=4$ ) (Fig. $10 \mathrm{~J}$ ). Moreover, the $\mathrm{A} \beta_{25-35}$-induced Et uptake was absent in astrocytes and neu- 


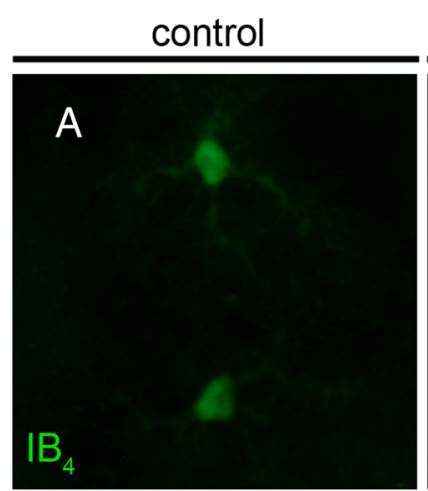

$\mathrm{A} \beta(3 \mathrm{~h}, 10 \mu \mathrm{M})$
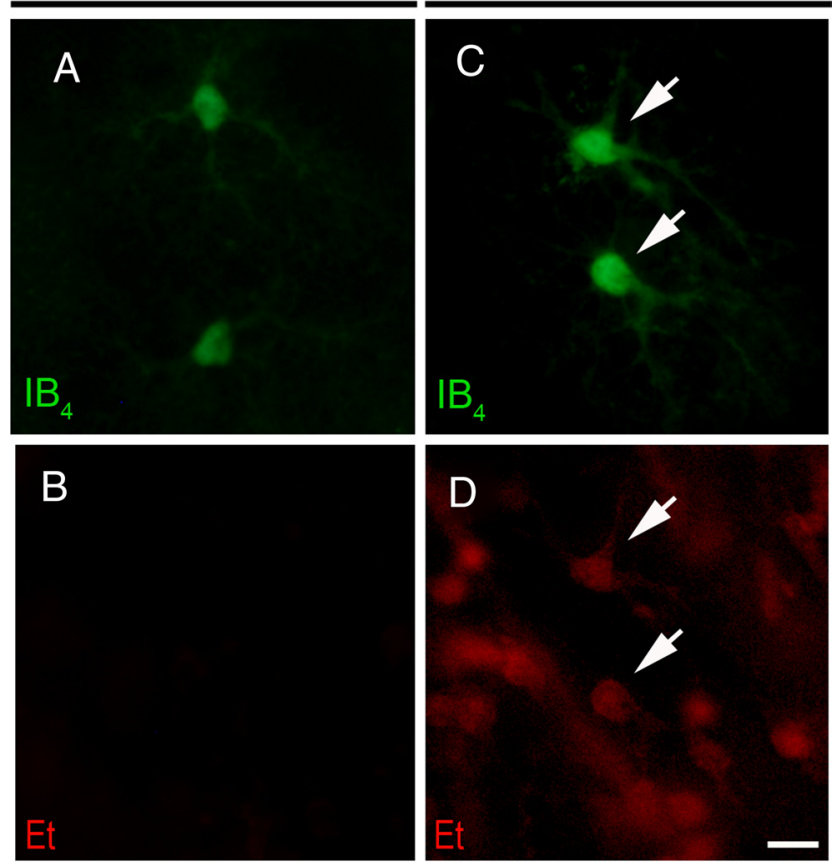

$\mathrm{E}$

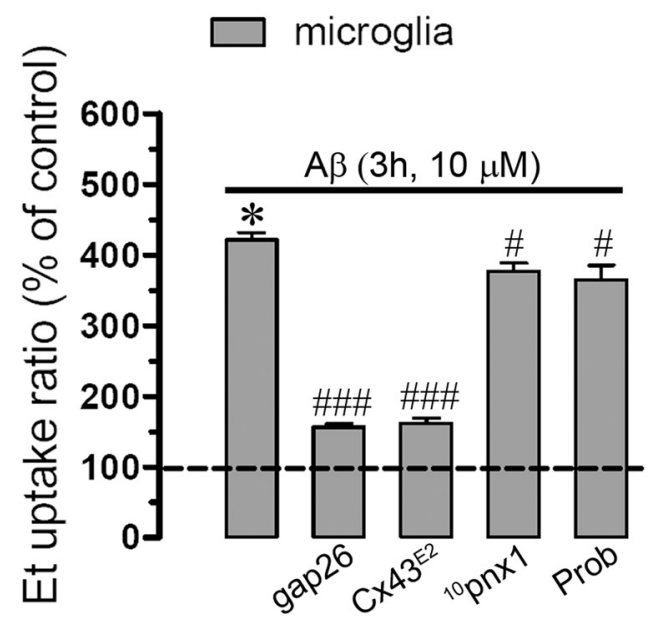

Figure 11. $A \beta_{25-35}$ increases the Et uptake in microglia of acute hippocampal slices. $\boldsymbol{A}-\boldsymbol{D}$, Representative images of acute hippocampal brain slices showing microglia positive for $\mathrm{IB}_{4}$ (green) and Et uptake (red) under control conditions $(\boldsymbol{A}, \boldsymbol{B})$ or treated for $3 \mathrm{~h}$ with $10 \mu \mathrm{m}$ $A \beta_{25-35}(\boldsymbol{C}, \boldsymbol{D}) . \boldsymbol{E}$, Averaged data normalized to control (dashed line) of Et uptake rate of hippocampal microglia treated with $A \beta_{25-35}(10 \mu \mathrm{m} ; 3 \mathrm{~h})$ or treated with $A \beta_{25-35}$ plus the following blockers applied during dye uptake recording: Gap26 (200 $\mu \mathrm{M}), \mathrm{C} \times 43^{\mathrm{E} 2}$, Prob (500 $\mu \mathrm{M})$, or ${ }^{10}$ panx1 $(200 \mu \mathrm{m})$. Averaged data were obtained from three independent experiments. ${ }^{*} p<0.005$, effect of $10 \mu \mathrm{m} \mathrm{A} \beta_{25-35}$ for 3 h compared with control; ${ }^{*} p<0.05$, \#\# $p<0.001$, effect of each blocker compared with the respective effect induced by $10 \mu \mathrm{M} \mathrm{A} \beta_{25-35}$ for $3 \mathrm{~h}$. Scale bar, $20 \mu \mathrm{m}$. Error bars indicate SEM.

rons from $\mathrm{Cx} 30^{-1-} \mathrm{Cx} 43^{\mathrm{fl} / \mathrm{fl}}$ : GFAP-cre $\left(\mathrm{Cx} 30^{-/-} \mathrm{Cx} 43^{-/-}\right)$ or $\mathrm{Cx} 43^{\mathrm{fl} / \mathrm{fl}}$ : GFAP-cre $\left(\mathrm{Cx} 43^{-/-}\right)$mice $(48.8 \pm 21.0$ or $52.9 \pm$ 22.7 and $119.9 \pm 21.2$ and $112.3 \pm 19.8 \%$ compared with control, respectively; $n=3$ ) (Fig. $10 \mathrm{~J}$ ). This last observation suggests that $\mathrm{Cx} 43$ hemichannel opening in astrocytes is required to observe membrane permeabilization in neurons. Importantly, $\mathrm{A} \beta_{25-35}$ also induced an increase in Et uptake in microglia of hippocampal slices (Fig. $11 A-E$ ). Moreover, the $\mathrm{A} \beta_{25-35}$-induced Et uptake was almost completely blocked with $\mathrm{Cx} 43^{\mathrm{E} 2}$ and Gap26 (from $421.2 \pm 23.3$ to $156.1 \pm 11.2$ and $162.2 \pm 15.3 \%$, respectively;

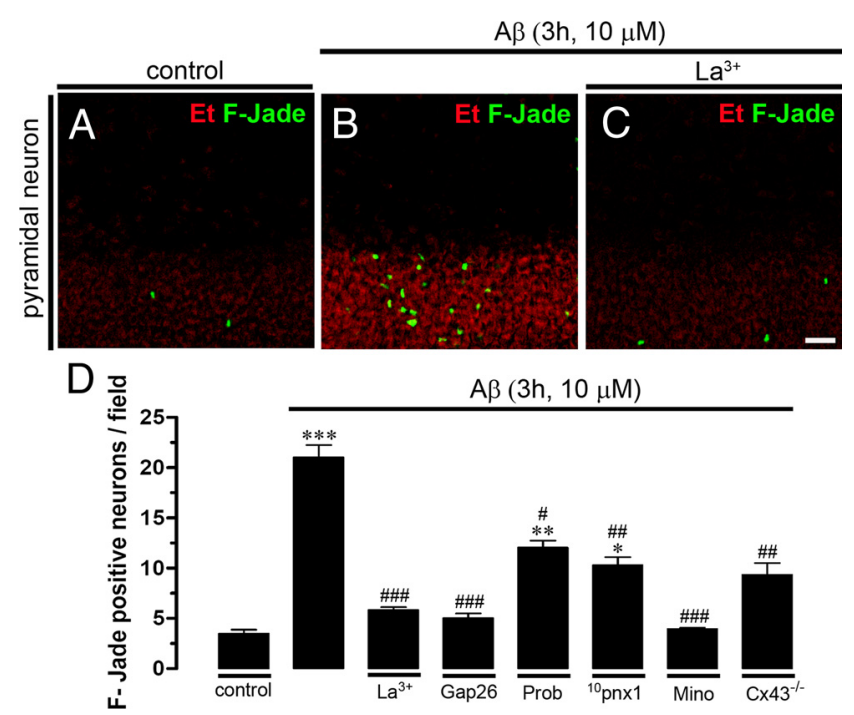

Figure 12. Blockade of connexin and pannexin hemichannels reduces neuronal death induced by $A \beta_{25-35}$ in acute hippocampal slices. $\boldsymbol{A}-\boldsymbol{C}$, Representative images of Et uptake (red) and F-Jadepositivestaining (green) by pyramidal neurons under control conditions $(A)$ or treated for $A \beta_{25-35}(10$ $\mu \mathrm{m} ; 3 \mathrm{~h}$ ) alone (B) or plus $200 \mu \mathrm{m} \mathrm{La}{ }^{3+}$ (C). D, Averaged number of F-Jade-positive cells per field of pyramidal neurons under control conditions or treated for $3 \mathrm{~h}$ with $A \beta_{25-35}(10 \mu \mathrm{m})$. Shown is the effect of La ${ }^{3+}(200 \mu \mathrm{M})$, Gap26 $(200 \mu \mathrm{M}), \operatorname{Prob}(500 \mu \mathrm{M}),{ }^{10} \operatorname{panx1}(200 \mu \mathrm{M})$, or minocycline (Mino) $(10 \mu \mathrm{M})$. Also shown is the neuronal death in hippocampal astrocytes of $\left(x 43^{\mathrm{f} / \mathrm{flf}}\right.$ : GFAP-cre $\left(\mathrm{Cx} 43^{-I-}\right)$ mice. ${ }^{* * *} p<0.001,{ }^{* *} p<0.005,{ }^{*} p<0.05$, compared with control. ${ }^{\# \#} p<0.001$, ${ }^{\# \#} p<0.005, \# p<0.05$, respective blocker effect compared with the $A \beta(10 \mu \mathrm{m} ; 3 \mathrm{~h})$ effect. Averaged data obtained from five independent experiments. Scale bar, $80 \mu \mathrm{m}$. Error bars indicate SEM.

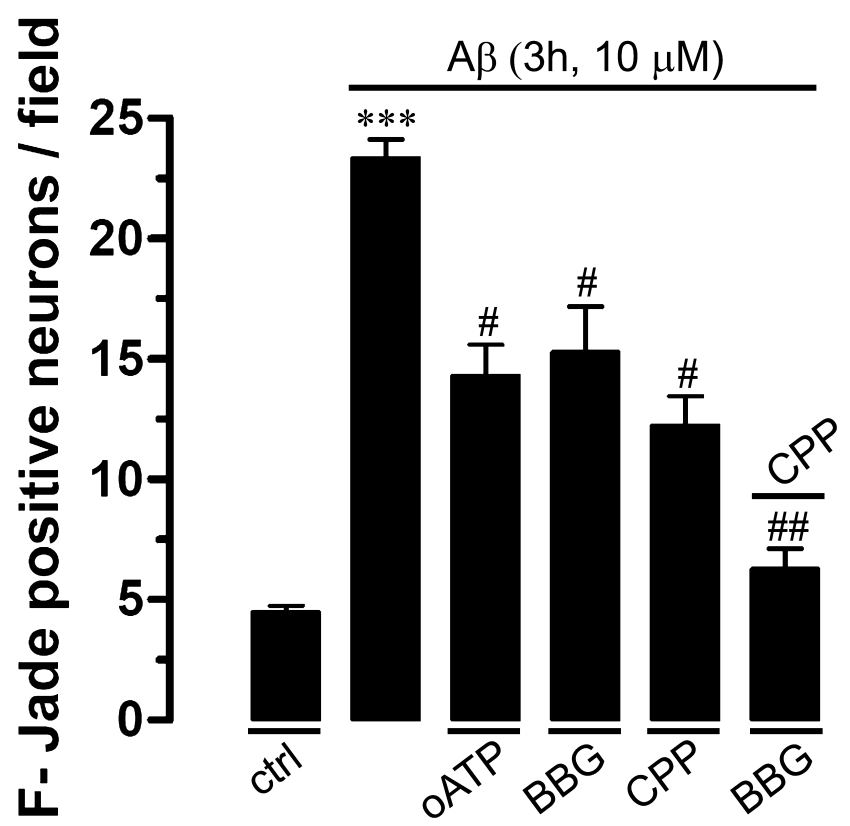

Figure 13. Blockade of NMDA/P2X receptors reduces neuronal death induced by $A \beta_{25-35}$ in acute hippocampal slices. Averaged number of $\mathrm{F}$-Jade-positive cells per field of pyramidal neurons under control conditions or treated for $3 \mathrm{~h}$ with $\mathrm{A} \beta_{25-35}(10 \mu \mathrm{m})$. Shown is the effect of $200 \mu \mathrm{M}$ OATP (P2X $\mathrm{X}_{7}$ receptor blocker), $10 \mu \mathrm{m} \mathrm{BBG}$ (P2X 7 receptor blocker), or $20 \mu \mathrm{m}$ CPP (NMDA receptor blocker). ${ }^{*} p<0.005, A \beta_{25-35}$ effect compared with control; ${ }^{*} p<0.005$, effect of blocker on $A \beta_{25-35}$ treatment. Averaged data are obtained from four independent experiments. Error bars indicate SEM.

$n=3$ ) (Fig. $11 E$ ), but weakly inhibited by probenecid and ${ }^{10}$ panx1 (from $421.2 \pm 23.3$ to $376.1 \pm 27.4$ and $365.3 \pm 45.3 \%$, respectively; $n=3$ ) (Fig. $11 E$ ), indicating that under this condition Cx43 hemichannels are the main pathway for Et uptake in microglia of brain slices. 


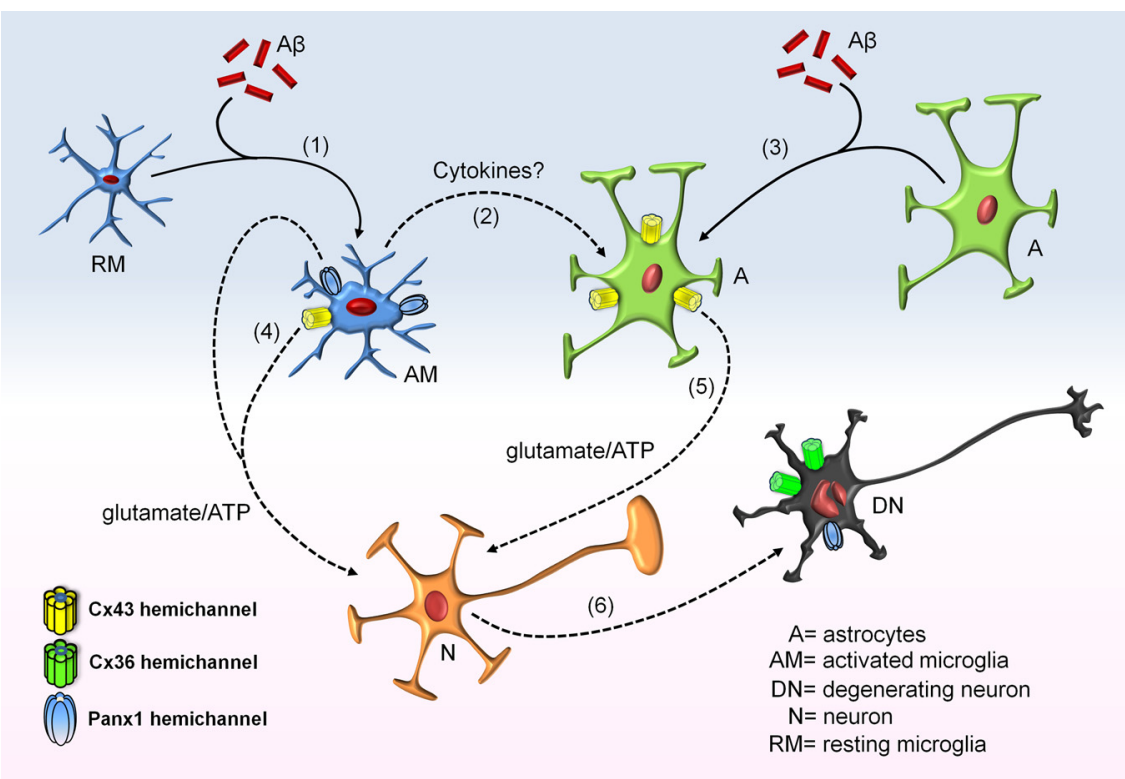

Figure 14. Model of $A \beta$-induced cascade resulting in glial and neuronal hemichannel activation leading to neuronal death. Microglia exposed to $A \beta$ peptide become first activated (1), leading to more opening of $\mathrm{C} x 43$ and Panx 1 hemichannels. Under these conditions, they release proinflammatory cytokines (2) that contribute to the $A \beta$-induced $C x 43$ hemichannel opening in astrocytes (3). Activated microglia might release glutamate and ATP through hemichannels (4), whereas astrocytes could release the same molecules through $\mathrm{C} \times 43$ hemichannels (5). This gliotransmission activates neuronal purinergic and NMDA receptors, resulting in an elevation of the intracellular free $\mathrm{Ca}^{2+}$ concentration that might trigger massive $\mathrm{C} \times 36$ and Panx1 hemichannel opening increase neuronal vulnerability to ATP and glutamate (6).

\section{$A \boldsymbol{\beta}_{25-35}$ induces neuronal death through increased glial hemichannel activity}

We also investigated whether opening of neuronal hemichannels induced by $\mathrm{A} \beta_{25-35}$ in hippocampal slices is involved in the known $\mathrm{A} \beta_{25-35}$-induced neuronal death (Pike et al., 1995b). Under control conditions, most neurons were negative for F-Jade staining (3.4 \pm 0.6 neurons/field; $n=5$ ) (Fig. $12 A, D)$, but after $3 \mathrm{~h}$ treatment with $10 \mu \mathrm{M} \mathrm{A} \beta_{25-35}$ numerous pyramidal neurons were F-Jade positive (21.1 \pm 0.3 neurons/field; $n=5)$ (Fig. $12 B, D)$. The neuronal death response was greatly reduced in slices pretreated either with $\mathrm{La}^{3+}$ and Gap26 (5.8 \pm 0.4 and $5.1 \pm$ 0.8 neurons/field, respectively; $n=5$ ) (Fig. $12 D$ ), whereas probenecid and ${ }^{10}$ pnx 1 caused a less prominent reduction in $\mathrm{A} \beta_{25-35}$-induced neuronal death $(12.1 \pm 1.2$ and $10.2 \pm 1.4$ neurons/field, respectively; $n=5$ ) (Fig. $12 D$ ). Moreover, reduced neuronal death was also observed in slices made from $\mathrm{Cx} 43^{\mathrm{fl} / \mathrm{fl}}$ : GFAP-cre $\left(\mathrm{Cx}_{4} 3^{-\prime-}\right)$ mice $(9.4 \pm 1.7$ neurons/field; $n=3)$ (Fig. $12 D$ ), supporting the central role of astroglial $\mathrm{Cx} 43$ hemichannels in this process. Finally, pretreatment with minocycline, an inhibitor of microglial activation, greatly reduced the number of dead neurons, suggesting that microglial activation could be an upstream required step for $\mathrm{A} \beta_{25-35}$-induced neuronal death. Consequently, the $\mathrm{A} \beta_{25-35}$-induced neuronal death seems to be dependent mainly of astroglial $\mathrm{Cx} 43$ hemichannel and neuronal Panx1 hemichannel activity. In support of this interpretation, either NMDA or P2X receptor blockers partially reduced the $\mathrm{A} \beta_{25-35}$-induced neuronal death (Fig. 13), but the combination of both receptor blockers induced a stronger inhibition.

\section{Discussion}

$A \beta_{25-35}$ triggers a sequential activation of hemichannels in glial cells and neurons

Using separate primary cultures to discriminate the molecular actors of $\mathrm{A} \beta_{25-35}$-induced Et uptake, we found that, in agreement with their sensor role in the CNS (Block et al., 2007), microglia show high hemichannel activity after short periods of incubation with low $\mathrm{A} \beta_{25-35}$ concentrations. As the $\mathrm{A} \beta_{25-35}$-induced hemichannel activity in microglia was partially prevented either by Cx43 or Panx1 hemichannel blockers and because microglia from $\mathrm{Cx} 43^{-1-}$ mouse showed a minor response, both hemichannel types are involved. This was confirmed by the complete block of $\mathrm{A} \beta_{25-35}$-induced currents with a combination of Panxl and Cx43 hemichannel blockers.

Astrocytes were more sensitive to $\mathrm{A} \beta_{25-35}$ than neurons, since for long incubation periods lower concentrations of $\mathrm{A} \beta_{25-35}$ were required to trigger Et uptake in astrocytes than in neurons. Moreover, the $\mathrm{A} \beta_{25-35}$-induced Et uptake was attributable to $\mathrm{Cx} 43$ hemichannels as it occurred in astrocytes from wild-type but not from $\mathrm{Cx} 43^{-1-}$ mice. Second, pharmacological treatments known to block Cx43 (Evans and Leybaert, 2007) but not Panx1 hemichannels and an antibody $\left(\mathrm{Cx} 43^{\mathrm{E} 2}\right)$ used to block only $\mathrm{Cx} 43$ hemichannels (Siller-Jackson et al., 2008) completely inhibited the astroglial $\mathrm{A} \beta_{25-35^{-}}$ induced Et uptake. Third, the astroglial $\mathrm{A} \beta_{25-35}$-induced currents with a unitary conductance compatible with Cx43 hemichannels ( $\sim 220$ pS) (Sáez et al., 2005) were completely blocked using only blockers of these channels and were absent in astrocytes of $\mathrm{Cx} 43^{-/-}$mice. Finally, Panx1 hemichannel blockers (Pelegrin and Surprenant, 2006; Silverman et al., 2008; Thompson et al., 2008), ${ }^{10}$ panx1 and E1b as well as probenecid, did not affect astroglial $\mathrm{A} \beta_{25-35}$-induced Et uptake.

In neurons, only long periods of incubation and high concentrations of $\mathrm{A} \beta_{25-35}$ induced Et uptake, which was drastically blocked by $\mathrm{La}^{3+}$, a general connexin hemichannel blocker, and was partially reduced by Panx1 hemichannel blockers. These results were supported by electrophysiological data in which the $\mathrm{A} \beta_{25-35}$-induced currents also were completely blocked with $\mathrm{La}^{3+}$ in combination with probenecid, a Panx1 hemichannel blocker. In addition, because part of the neuronal unitary events induced by $\mathrm{A} \beta_{25-35}$ were compatible with the expected conductance of Cx36 hemichannels ( 30 pS) (Sáez et al., 2005), we suggest that Panx1 and possibly a putative hemichannel composed by $\mathrm{Cx} 36$ are the main contributors in this response. In agreement with this possibility, $\mathrm{Cx} 36$ has been detected in GABAergic interneurons and pyramidal cells (Götz and Bolz, 1994; Wellershaus et al., 2008; Köster-Patzlaff et al., 2009). In addition, Panx1 has been shown to present a ubiquitous expression in brain cells (Orellana et al., 2009).

Here, we observed that $\mathrm{A} \beta_{25-35}$ increased the surface level of $\mathrm{Cx} 43$ in microglia and astrocytes and showed for the first time that surface Panx1 is increased in $A \beta_{25-35}$-treated microglia. Panx1 was also detected in astrocytes, but not at their surface in the absence or presence of $A \beta_{25-35}$, which is in disagreement with a recent study in which astroglial Panx1 hemichannels were shown to be activated by extracellular ATP (Iglesias et al., 2009). This could be explained by the limited detection of low levels of this protein at the surface using biotinylation/Western blot as- 
says. Also, several possible sources of variations including feeding time and timing between plating and desired cell density before the experiments could explain this disagreement. The surface increase of Cx43 in astrocytes and Cx43/Panx1 in microglia is likely enough to account for the observed increase in hemichannel activity. In neurons, Cx36 or Panx1 were detected as previously reported (Huang et al., 2007; Schock et al., 2008); however, only changes in Panx1 surface levels were observed. Alternatively, the increase in hemichannel activity might be explained by enhanced open probability or channel permeability resulting from covalent modifications (e.g., phosphorylation and/or S-nitrosylation).

\section{$A \beta$-induced neuronal death occurs through a sequence of hemichannel activation}

The $\mathrm{A} \beta$ pathway hypothesis of $\mathrm{AD}$ states that this peptide disrupts synaptic function and can lead to neuronal loss directly (LaFerla et al., 2007) or indirectly by activation of glial cells (Akiyama et al., 2000). Here, we demonstrated that glial hemichannel activation is necessary for $\mathrm{A} \beta_{25-35}$-induced neuronal death in cellular cultures. Importantly, the $\mathrm{A} \beta_{25-35}$-induced hemichannel activity was more prominent after $72 \mathrm{~h}$ of incubation, which could be explained because aggregation of $\mathrm{A} \beta_{25-35}$ is correlated with its neurotoxicity and is a time-dependent process (Pike et al., 1995a). Although separated cultures allow us to dissect in detail the $\mathrm{A} \beta_{25-35^{-}}$ induced hemichannel activity in individual cellular types, the use of acute hippocampal slices was essential to study this response in a more integrated system. Up to now, the presence of functional hemichannels in brain slices (Liu et al., 2006; Rouach et al., 2008; Stridh et al., 2008) was solely observed under extracellular $\mathrm{Ca}^{2+} / \mathrm{Mg}^{2+}$-free condition, a protocol that promotes hemichannel opening but does not reflect a physiological situation. Here, we show that $\mathrm{A} \beta_{25-35}$ induces hemichannel activity in hippocampal microglia, astrocytes, and neurons under normal extracellular divalent cationic conditions. Thus, the combination of this integrated preparation along with the separated primary cultures allows us to identify and dissect the sequence of events involved in the cellular responses to $\mathrm{A} \beta_{25-35}$ (Fig. 14). Initially, microglia are more sensitive and likely react to $\mathrm{A} \beta_{25-35}$ before astrocytes and neurons, since low concentrations and short time of incubation with this peptide generate hemichannel activity. Accordingly, minocycline, which blocks mainly microglial activation (Dutta et al., 2008), prevented the astroglial and neuronal $\mathrm{A} \beta_{25-35}$-induced Et uptake in hippocampal slices, indicating that this change could be an initial response to $\mathrm{A} \beta_{25-35}$ triggered in these cells. Microglial activation by A $\beta_{25-35}$ (Fig. $8 A-C$ ) then leads to the release of TNF- $\alpha$ and IL- $1 \beta$ (interleukin- $1 \beta$ ), which are known to activate astroglial $\mathrm{Cx} 43$ hemichannels (Retamal et al., 2007). In addition, these cytokines are produced by A $\beta$-treated microglia (Meda et al., 1999) and their mRNA expression is increased in these cells at amyloid plaques (Hickman et al., 2008). Accordingly, astroglial hemichannel activity could be triggered directly by action of $\mathrm{A} \beta_{25-35}$ and by the release of proinflammatory cytokines from microglia (Fig. 14).

Conditioned media harvested either from $\mathrm{A} \beta_{25-35}$-treated microglia or astrocytes, increased neuronal Et uptake and mortality, an effect prevented by CPP plus BBG, indicating that ATP and glutamate contribute to these changes. The contribution of these two molecules in neurotoxicity is well known (Lipton and Rosenberg, 1994) and the involvement of hemichannels in glutamate and ATP release has also been documented (Ye et al., 2003; Takeuchi et al., 2006; Kang et al., 2008). Their effect on neuronal death may proceed according to at least two mechanisms: either through the stimulation of NMDA and/or P2X receptors or through connexin and Panx1 hemichannels themselves that are permeable to $\mathrm{Ca}^{2+}$ and thus can evoke large influxes resulting in neuronal death (Orellana et al., 2009). Moreover, these two mechanisms could also be linked since transient activation of NMDA receptors induced a nonselective cationic current that develops slowly and mediates $\mathrm{Ca}^{2+}$ influx directly linked to neuronal death. Interestingly, this secondary current was reported recently to be mediated by neuronal Panxl hemichannels (Thompson et al., 2008). This idea is in agreement with the neuroprotective effect of NMDA/P2X receptor blockade in $\mathrm{A} \beta_{25-35^{-}}$ treated slices. Moreover, activation of Panx 1 hemichannels might be triggered by protein-protein interaction with activated $\mathrm{P} 2$ receptors (Iglesias et al., 2008). Alternatively, Panx1 hemichannels could be activated because of the rise in $\left[\mathrm{Ca}^{2+}\right]_{i}$ caused by opening of NMDA and P2X receptors (Locovei et al., 2006). In this mechanism, neuronal ATP released as a result of Panx1 hemichannel opening is also likely to contribute in the progression of neuronal death by a vicious cycle since it will activate more ionotropic $\mathrm{P} 2$ receptors leading to more $\mathrm{Ca}^{2+}$ entry and activation of intracellular neurotoxic cascades. Finally, dead neurons might be sensed by microglia (Beyer et al., 2000), which could be either partially activated or under resting condition. Consequently, neuronal debris detected by microglia could enhance and/or extend the period of time in which the neurotoxic cascade is active. Finally, slice experiments indicates that astroglial $\mathrm{Cx} 43$ hemichannel activity constitutes a prerequisite condition for the action of $\mathrm{A} \beta_{25-35}$ on neuronal hemichannels, since this peptide did not increase Et uptake in neurons of hippocampal slices made from $\mathrm{Cx} 43^{\mathrm{fl} / \mathrm{fl}}$ : GFAP-cre $\left(\mathrm{Cx} 43^{-/-}\right)$mice. Moreover, activation of microglia hemichannels occurred within the $3 \mathrm{~h}$ treatment with $\mathrm{A} \beta_{25-35}$, indicating that the involvement of microglia activation observed in cultured cells is also operating in brain slices.

\section{Pathological significance}

Astroglial Cx43 expression is increased at amyloid plaques from patients with AD (Nagy et al., 1996; Mei et al., 2010), whereas connexin-mediated astroglial networks and in vivo intercellular calcium waves are increased in AD transgenic mouse models (Kuchibhotla et al., 2009; Peters et al., 2009) (but see Cruz et al., 2010). We are aware that our culture or acute slice models do not recapitulate completely the mechanisms that occur during $\mathrm{AD}$, but they allow dissecting the specific contribution of each kind of hemichannel expressed by individual cellular types exposed to $\mathrm{A} \beta_{25-35}$. Therefore, our results could explain the early phases of the increase of $\mathrm{A} \beta$ in $\mathrm{AD}$ and indicate how glial cells react to these phenomena, ultimately affecting neuronal survival. Additional studies using $\mathrm{AD}$ transgenic mice will be necessary to elucidate the contribution of glial and neuronal hemichannels to the development of this disease. Thus, the present demonstration of a sequential activation of hemichannels composed by $\mathrm{Cx} 43$, Panx 1 , and Cx36 depending on the cell type should contribute to the potential development of novel pharmacological strategies for the treatment of $\mathrm{AD}$.

\section{References}

Akiyama H, Arai T, Kondo H, Tanno E, Haga C, Ikeda K (2000) Cell mediators of inflammation in the Alzheimer disease brain. Alzheimer Dis Assoc Disord 14 [Suppl 1]:S47-S53.

Allaman I, Gavillet M, Bélanger M, Laroche T, Viertl D, Lashuel HA, Magistretti PJ (2010) Amyloid- $\beta$ aggregates cause alterations of astrocytic metabolic phenotype: impact on neuronal viability. J Neurosci 30:3326-3338.

Bao L, Locovei S, Dahl G (2004) Pannexin membrane channels are mechanosensitive conduits for ATP. FEBS Lett 572:65-68.

Beyer M, Gimsa U, Eyüpoglu IY, Hailer NP, Nitsch R (2000) Phagocytosis of 
neuronal or glial debris by microglial cells: upregulation of MHC class II expression and multinuclear giant cell formation in vitro. Glia 31:262-266.

Block ML, Zecca L, Hong JS (2007) Microglia-mediated neurotoxicity: uncovering the molecular mechanisms. Nat Rev Neurosci 8:57-69.

Cruz NF, Ball KK, Dienel GA (2010) Astrocytic gap junctional communication is reduced in amyloid-beta-treated cultured astrocytes, but not in Alzheimer's disease transgenic mice. ASN Neuro 2:pii:e00041.

Dutta G, Zhang P, Liu B (2008) The lipopolysaccharide Parkinson's disease animal model: mechanistic studies and drug discovery. Fundam Clin Pharmacol 22:453-464.

Eugenín EA, Brañes MC, Berman JW, Sáez JC (2003) TNF- $\alpha$ plus IFN- $\gamma$ induce connexin 43 expression and formation of gap junctions between human monocytes/macrophages that enhance physiological responses. J Immunol 170:1320-1328.

Evans WH, Leybaert L (2007) Mimetic peptides as blockers of connexin channel-facilitated intercellular communication. Cell Commun Adhes 14:265-273.

Genever PG, Skerry TM (2001) Regulation of spontaneous glutamate release activity in osteoblastic cells and its role in differentiation and survival: evidence for intrinsic glutamatergic signaling in bone. FASEB J 15:1586-1588.

Götz M, Bolz J (1994) Differentiation of transmitter phenotypes in rat cerebral cortex. Eur J Neurosci 6:18-32.

Hickman SE, Allison EK, El Khoury J (2008) Microglial dysfunction and defective $\beta$-amyloid clearance pathways in aging Alzheimer's disease mice. J Neurosci 28:8354-8360.

Huang Y, Grinspan JB, Abrams CK, Scherer SS (2007) Pannexin1 is expressed by neurons and glia but does not form functional gap junctions. Glia 55:46-56.

Iglesias R, Locovei S, Roque A, Alberto AP, Dahl G, Spray DC, Scemes E (2008) $\mathrm{P} 2 \mathrm{X}_{7}$ receptor-Pannexin 1 complex: pharmacology and signaling. Am J Physiol Cell Physiol 295:C752-C760.

Iglesias R, Dahl G, Qiu F, Spray DC, Scemes E (2009) Pannexin 1: the molecular substrate of astrocyte "hemichannels." J Neurosci 29:7092-7097.

Kalaria RN (1999) The blood-brain barrier and cerebrovascular pathology in Alzheimer's disease. Ann N Y Acad Sci 893:113-125.

Kang J, Kang N, Lovatt D, Torres A, Zhao Z, Lin J, Nedergaard M (2008) Connexin 43 hemichannels are permeable to ATP. J Neurosci 28: $4702-4711$.

Köster-Patzlaff C, Hosseini SM, Reuss B (2009) Loss of connexin36 in rat hippocampus and cerebellar cortex in persistent Borna disease virus infection. J Chem Neuroanat 37:118-127.

Kuchibhotla KV, Lattarulo CR, Hyman BT, Bacskai BJ (2009) Synchronous hyperactivity and intercellular calcium waves in astrocytes in Alzheimer mice. Science 323:1211-1215

LaFerla FM, Green KN, Oddo S (2007) Intracellular amyloid-beta in Alzheimer's disease. Nat Rev Neurosci 8:499-509.

Lipton SA, Rosenberg PA (1994) Excitatory amino acids as a final common pathway for neurologic disorders. N Engl J Med 330:613-622.

Liu X, Bolteus AJ, Balkin DM, Henschel O, Bordey A (2006) GFAP-expressing cells in the postnatal subventricular zone display a unique glial phenotype intermediate between radial glia and astrocytes. Glia 54:394-410.

Locovei S, Wang J, Dahl G (2006) Activation of pannexin 1 channels by ATP through P2Y receptors and by cytoplasmic calcium. FEBS Lett 580: 239-244.

Meda L, Baron P, Prat E, Scarpini E, Scarlato G, Cassatella MA, Rossi F (1999) Proinflammatory profile of cytokine production by human monocytes and murine microglia stimulated with beta-amyloid[25-35]. J Neuroimmunol 93:45-52.

Mei X, Ezan P, Giaume C, Koulakoff A (2010) Astroglial connexin immunoreactivity is specifically altered at beta-amyloid plaques in betaamyloid precursor protein/presenilin1 mice. Neuroscience 171:92-105.

Nagy JI, Li W, Hertzberg EL, Marotta CA (1996) Elevated connexin43 immunoreactivity at sites of amyloid plaques in Alzheimer's disease. Brain Res 717:173-178.

Noraberg J, Kristensen BW, Zimmer J (1999) Markers for neuronal degeneration in organotypic slice cultures. Brain Res Brain Res Protoc 3:278-290.

Orellana JA, Sáez PJ, Shoji KF, Schalper KA, Palacios-Prado N, Velarde V, Giaume C, Bennett MV, Sáez JC (2009) Modulation of brain hemichannels and gap junction channels by pro-inflammatory agents and their possible role in neurodegeneration. Antioxid Redox Signal 11:369-399.

Orellana JA, Hernández DE, Ezan P, Velarde V, Bennett MV, Giaume C, Sáez
JC (2010) Hypoxia in high glucose followed by reoxygenation in normal glucose reduces the viability of cortical astrocytes through increased permeability of connexin 43 hemichannels. Glia 58:329-343.

Pelegrin P, Surprenant A (2006) Pannexin-1 mediates large pore formation and interleukin-1beta release by the ATP-gated $\mathrm{P} 2 \mathrm{X}_{7}$ receptor. EMBO J 25:5071-5082.

Peters O, Schipke CG, Philipps A, Haas B, Pannasch U, Wang LP, Benedetti B, Kingston AE, Kettenmann H (2009) Astrocyte function is modified by Alzheimer's disease-like pathology in aged mice. J Alzheimers Dis 18:177-189.

Pike CJ, Walencewicz-Wasserman AJ, Kosmoski J, Cribbs DH, Glabe CG, Cotman CW (1995a) Structure-activity analyses of beta-amyloid peptides: contributions of the beta $25-35$ region to aggregation and neurotoxicity. J Neurochem 64:253-265.

Pike CJ, Overman MJ, Cotman CW (1995b) Amino-terminal deletions enhance aggregation of beta-amyloid peptides in vitro. J Biol Chem 270:23895-23898.

Reaume AG, de Sousa PA, Kulkarni S, Langille BL, Zhu D, Davies TC, Juneja SC, Kidder GM, Rossant J (1995) Cardiac malformation in neonatal mice lacking connexin43. Science 267:1831-1834.

Retamal MA, Froger N, Palacios-Prado N, Ezan P, Sáez PJ, Sáez JC, Giaume C (2007) Cx43 hemichannels and gap junction channels in astrocytes are regulated oppositely by proinflammatory cytokines released from activated microglia. J Neurosci 27:13781-13792.

Rouach N, Koulakoff A, Abudara V, Willecke K, Giaume C (2008) Astroglial metabolic networks sustain hippocampal synaptic transmission. Science 322:1551-1555.

Sáez JC, Berthoud VM, Brañes MC, Martínez AD, Beyer EC (2003) Plasma membrane channels formed by connexins: their regulation and functions. Physiol Rev 83:1359-1400.

Sáez JC, Retamal MA, Basilio D, Bukauskas FF, Bennett MV (2005) Connexin-based gap junction hemichannels: gating mechanisms. Biochim Biophys Acta 1711:215-224

Scemes E, Spray DC, Meda P (2009) Connexins, pannexins, innexins: novel roles of "hemi-channels." Pflugers Arch 457:1207-1226.

Schmuck G, Kahl R (2009) The use of Fluoro-Jade in primary neuronal cell cultures. Arch Toxicol 83:397-403.

Schock SC, Leblanc D, Hakim AM, Thompson CS (2008) ATP release by way of connexin 36 hemichannels mediates ischemic tolerance in vitro. Biochem Biophys Res Commun 368:138-144.

Shestopalov VI, Panchin Y (2008) Pannexins and gap junction protein diversity. Cell Mol Life Sci 65:376-394.

Siller-Jackson AJ, Burra S, Gu S, Xia X, Bonewald LF, Sprague E, Jiang JX (2008) Adaptation of connexin 43-hemichannel prostaglandin release to mechanical loading. J Biol Chem 283:26374-26382.

Silverman W, Locovei S, Dahl G (2008) Probenecid, a gout remedy, inhibits pannexin 1 channels. Am J Physiol Cell Physiol 295:C761-C767.

Stridh MH, Tranberg M, Weber SG, Blomstrand F, Sandberg M (2008) Stimulated efflux of amino acids and glutathione from cultured hippocampal slices by omission of extracellular calcium: likely involvement of connexin hemichannels. J Biol Chem 283:10347-10356.

Takeuchi H, Jin S, Wang J, Zhang G, Kawanokuchi J, Kuno R, Sonobe Y, Mizuno T, Suzumura A (2006) Tumor necrosis factor-alpha induces neurotoxicity via glutamate release from hemichannels of activated microglia in an autocrine manner. J Biol Chem 281:21362-21368.

Thompson RJ, Zhou N, MacVicar BA (2006) Ischemia opens neuronal gap junction hemichannels. Science 312:924-927.

Thompson RJ, Jackson MF, Olah ME, Rungta RL, Hines DJ, Beazely MA, MacDonald JF, MacVicar BA (2008) Activation of pannexin-1 hemichannels augments aberrant bursting in the hippocampus. Science 322:1555-1559.

Wang J, Ma M, Locovei S, Keane RW, Dahl G (2007) Modulation of membrane channel currents by gap junction protein mimetic peptides: size matters. Am J Physiol Cell Physiol 293:C1112-C1119.

Wellershaus K, Degen J, Deuchars J, Theis M, Charollais A, Caille D, Gauthier B, Janssen-Bienhold U, Sonntag S, Herrera P, Meda P, Willecke K (2008) A new conditional mouse mutant reveals specific expression and functions of connexin 36 in neurons and pancreatic beta-cells. Exp Cell Res 314:997-1012.

Ye ZC, Wyeth MS, Baltan-Tekkok S, Ransom BR (2003) Functional hemichannels in astrocytes: a novel mechanism of glutamate release. J Neurosci $23: 3588-3596$ 